\title{
IN THE TRADITION OR OUTSIDE? Reflections on Teachers and Influences
}

\author{
Martin van Bruinessen \\ Department of Philosophy and Religious Studies, \\ Utrecht University, The Netherlands \\ email:m.vanbruinessen@uu.nl
}

\section{Abstract}

In this autobiographical essay, Martin van Bruinessen looks back at the diverse intellectual influences that contributed to his formation as a scholar of Indonesian Islam. He was never trained as an Indonesianist or a scholar of Islam, and came to the subject through a series of unplanned changes in his life trajectory. His first acquaintance with Indonesia was through late colonial and post-colonial Dutch literature. It was followed in his student days by critical reporting on the massacres of 1965-66 and a re-reading of Indonesian history from an anti-imperialist viewpoint. His formal academic training was in entirely different disciplines, and his first experience with anthropological fieldwork took place in a different part of the world. A fortuitous post-doctoral appointment at KITLV, followed by four years at LIPI as a consultant for research methods, enabled him to acquaint himself directly with contemporary Muslim discourses and movements. He had the good fortune of working with leading Indonesian Muslim intellectuals, who became his major teachers. Only when be became a teacher and thesis supervisor bimself, at the IAIN Sunan Kalijaga and later at Utrecht University, did he feel the need to reflect on how his own research relates to established academic traditions. The essay documents his growing appreciation of, and lasting critical distance from, the Leiden school of Oriental studies and his relationship with the French tradition of Islamic and Indonesian studies. It also attempts to be the story of the rise and decline of Leiden's tradition of Indonesian Islamic studies, from the perspective of a critical reader who wishes to remain an outsider.

Dalam tulisan biografis ini, Martin van Buinessen melihat kembali beberapa 
pengaruh pembentukan dirinya sebagai sarjana tentang Islam Indonesia. Martin tidak belajar khusus tentang keindonesiaan atau keislaman, minat itu muncul dari perubahan-perubahan dalam hidupnya. Perkenalannya dengan Indonesia dimulai lewat tulisan-tulisan dari masa akbir dan pasca penjajahan. Pengalamannya berlanjut pada masa studinya saat menulis laporan kritis tentang kasus 1965-1966 dan dengan pembacaan ulangnya atas sejarah Indonesia dari sudut pandang anti imperalisme. Latar belakang pendidikan formalnya sama sekali berbeda, sementara pengalaman pertama riset antropologinya juga di tempat yang berbeda. Posisi post-doktoral di KITLV dan diikuti empat tahun di LIPI sebagai konsultan metodologi riset membuat Martin bersinggungan langsung dengan wacana muslim kontemporer dan gerakannya. Martin sangat beruntung bertemu dengan para cendikiawan muslim Indonesia yang kemudian menjadi guru-gurunya. Daripengalamannya menjadi dosen dan supervisor disertasi di IAIN Sunan Kalijaga, sekarang UIN Sunan Kalijaga, dan selanjutnya di Universitas Utrecht juga, Martin merasa perlu untuk merefleksikan kembali penelitiannya dalam kaitannya dengan tradisi akademik yang mapan. Tulisan ini mendokumentasikan perkembangan apresiasinya, sekaligus kritiknya, terbadap studi ketimuran mazhab Leiden serta keterkaitannya dengan studi keislaman dan keindonesiaan dalam tradisi Perancis. Ini juga merupakan upaya untuk. menulis sejarah naik-turunny studi keislaman Indonesia mað̧hab Leiden dari perspektif seorang pembaca kritis yang berusaha tetap menjadi 'orang luar'.]

Keywords: Indonesian Islamic Studies, Leiden tradition, scholarly reflection, genealogy, Dutch intellectual

\section{A. Introduction: Do Scholars Need a Silsila?}

In Sufi orders, one of the first things a student learns is the silsila of his teacher. Without the silsila, the teacher does not have much legitimacy. In hadith studies too, and in fiqh, as well as all the traditional Islamic sciences, the isnād is the essential legitimising factor. Without a proper isnäd, a hadith does not have much authority, and in the madrasa tradition, even the study of printed books demands the face-to-face contact of disciple and teacher, and the teacher has to have 'received' the book from a line of teachers preceding him, the isnád of the book. A Sufi teacher without a silsila is a teacher without a shaykh -and in the Naqshbandi tradition it is often said that "the person who does not have a shaykh, Satan is his guide." It is the silsila that connects the Sufi with a 
In the Tradition or Outside? Reflections on Teachers and Influences respectable (mu'tabar) spiritual and intellectual tradition.

We find in the history of Sufism an apparent exception to this rule: the uwaysi or barzakhi initiation. Some Sufis allegedly received their initiation not in face-to-face contact with a living shaykh but from the rübäniyya (spiritual essence) of a teacher long deceased, whom they met in dreams of visions. Even in the most orthodox of Sufi orders, the Naqshbandiyya, the silsila of the founder, Bahā' al-Dīn Naqshband, contains several such barzakhi connections across time gaps of more than a century. But this does not in any way diminish the importance given to the silsila in this or any other order.

A different case is that of the qalandar, the itinerant dervishes who cared little about rules and regulations, who in outward dress and behaviour violated the norms of the $\operatorname{shar}^{-6} a$, who did not follow any teacher's discipline, but who were intoxicated with love for God, which they expressed in often shocking words. The qalandar made a major impact on Sufi poetry, however, for they symbolised the ultimate detachment from the world and a relationship with God unrestrained by social norms and consisting of nothing but divine love. Shams-i Tabrizi, the dervish to whom Mawlana Jalāl al-Dīn Rūmī dedicated some of his most beautiful poetry, is the best-known icon of this variety of mysticism. The orthodox, however, are vary of these subversive mystics and have declared them beyond the pale, ghayr mu'tabar.

Modern scholarship is of course in many respects different from a spiritual tradition such as Sufism, but in each discipline there are schools or traditions with distinctive approaches and paradigms, and it is common for a scholar to be initiated in at least one of these schools. The work of many scholars is clearly marked by the tradition in which they were trained.

In my country, the Netherlands, the study of Indonesian Islam is a well-established tradition, in which Christiaan Snouck Hurgronje is certainly not the first but definitely the most towering figure. This scholarly tradition is intimately connected with the Dutch colonial venture in Indonesia. Snouck Hurgronje himself, who was always eager to place his learning at the service of the colonial government, exemplifies the interdependence of scholarship and colonial policy. The Bureau for Indigenous Affairs in Batavia and the school for colonial civil servants at Leiden University were core institutions where the study of Indonesian 
Islam was cultivated. ${ }^{1}$ A minor school of expertise on Indonesian Islam was also developed by the Catholic and Protestant missions, which were not part of the colonial government and had different interests. ${ }^{2}$

After Indonesia's Independence, a slow decline in all branches of Indonesian studies, including the study of Islam, set in. Most of the scholars who had been based in the Dutch Indies returned to the Netherlands, and some of them found positions at Leiden or another university, or in other government services. But because the prospect of a career in Indonesia was no longer available, the number of students in Indonesian studies gradually decreased. The scholars continued publishing, and in fact some of the best publications on Indonesian Islam were published after the colonial ties with Indonesia had been cut. However, the tradition lost vitality and produced few young scholars capable of continuing. By the 1980s, the last scholars trained in the colonial period were reaching the age of retirement. This was when, more or less by accident, I first became involved in the study of Indonesian Islam.

I have always thought of myself as an outsider in this field of study, a trespasser on territory claimed by a tradition of which I was not part. (In fact, after I had received my first post-doctoral grant at the KITLV in Leiden, I was told by a colleague of my own age who seemed to resent my appointment, "those grants were really meant for us" - meaning for those who had been trained in anthropology or the humanities in Leiden). I have no formal education in Indonesian or Islamic studies and am largely self-taught (but there have been colleagues from whom I learned much, later in life). I have often claimed to be a scholar without a silsila, without a shaykh, a qalandar rather than an uwaysi, and proud not to be part of the colonial past of my country. But looking back after more than thirty years, I am aware that I have attempted to connect myself to parts of the tradition, like an uwaysi seeking inspiration from specific scholars of the Dutch school as well as learning from some great non-Dutch scholars whom I met. In what follows, I shall sketch my gradual engagement with

${ }^{1}$ On the Bureau for Native Affairs, the chief advisers who worked there, and the various roles of the Bureau, see H. Aqib Suminto, Politik Islam Hindia Belanda (Jakarta: LP3ES, 1985), pp. 99-198; B.J. Boland and I. Farjon, Islam in Indonesia: A Bibliographical Survey, 1600-1942 with Post-1945 Addenda (Dordrecht: Foris Publications Holland, 1983), pp. 27-37.

${ }^{2}$ W. Otterspeer and L.H. Enklaar (eds.), "Leiden Orientalists and the Christian Mission”, in Leiden Oriental Connections: 1850 - 1940 (Leiden: E.J. Brill, 1989), pp. 168-86. Boland and Farjon, Islam in Indonesia, pp. 37-48. 
In the Tradition or Outside? Reflections on Teachers and Influences the Dutch and other traditions of Indonesian Islamic studies.

\section{B. First Acquaintance with Indonesian Studies}

My involvement with Indonesia began late in life, in 1982. I was 36 years old then and had already two half careers behind me. I had studied mathematics and theoretical physics and had worked as a mathematics teacher, and I had also studied some anthropology on the side and later made that my main occupation when I found a grant to do fieldwork --two years in Kurdistan, learning languages and living very close to people. I completed my dissertation in 1978, worked briefly in a development project in Afghanistan, spent some time in Iran during the Islamic revolution, taught Turkish at my university, and was planning a new research project in the Middle East but had no source of income and therefore had to apply for a real job. This is why I applied when in 1981 I saw an announcement that six postdoctoral fellowships were available at the main institute for research on Indonesia (KITLV), ${ }^{3}$ in various disciplines: history, archaeology, anthropology, and Islamic studies and field linguistics. I wrote that I was an anthropologist, with a $\mathrm{PhD}$ degree based on research among the Kurds, and I added that I has read almost nothing about Indonesia -I believe that I wrote, or else I told in my job interview, that I had only read Multatuli's novel Max Havelaar, which is perhaps the most famous Dutch novel. ${ }^{4}$ The selection committee told me that was no problem, and that it might even be an advantage to be tabula rasa, a blank slate: I might have an unprejudiced, fresh approach. They offered me the job; however, the appointment was not to be in anthropology but in the study of Indonesian Islam. Because in my dissertation on the Kurds I had paid much attention to the role of Sufi orders, they expected me to have useful background knowledge.

I realised later that they did not simply choose me because I was tabula rasa. My Ph.D. supervisor ('promotor') was Jan van Baal, a man who was highly respected in Indonesianist circles in the Netherlands

${ }^{3}$ The Institute's full name in Dutch is Koninklijk Instituut voor Taal-, Land- and Volkenkunde, but the name in English has changed over time, from Royal Institute of Linguistics and Anthropology to Royal Institute of Southeast Asian and Caribbean Studies.

${ }^{4}$ Multatuli (pseudonym of Eduard Douwes Dekker) had himself been in colonial government service. His novel Max Havelaar, first published in 1860, was an indictment of corruption and exploitation of the indigenous population in the forced cultivation system in Java. It is widely considered as one of the most important works of Dutch literature, and continues to be read. 
and who had a very strong network. I believe he must have pulled a few strings to get me a job. Van Baal had been a high-ranking civil servant in the colonial administration, serving in Java, Lombok, and Bali and finally as one of the last governors of the last part of the Indies that remained under Dutch control, New Guinea (from 1953 to 1958). After his return to the Netherlands, he held various influential positions and was professor of anthropology in Amsterdam and Utrecht. His main interest was in the anthropology of religion, but also in the structural analysis of complex kinship systems, and as a student I drew his attention because I wrote a paper on the mathematical analysis of such kinship systems. It was due to his support that I was later able to make the change from mathematics and physics to anthropology. He took me on as his Ph.D. student and remained my mentor afterwards. But let me first take a step further back into my past before I say more about my training in anthropology.

\section{Early Acquaintance with Indonesian Culture}

It was not exactly true that I my only source of knowledge about Indonesia had been the novel Max Havelaar, although that was the single book on Indonesia that I remembered then. And I was not so ignorant of Indonesia as I claimed, or believed, I was. As I am growing older, earlier memories have started coming back and I realise that from an early age on I have in fact absorbed knowledge of Indonesia that was simply around everywhere in the Netherlands, in literature as well as popular music, in my geography textbooks in school and in the art collections of museums, in newspapers and political tracts, and in many everyday Dutch expressions, which appeared to have Malay origins.

When I made my first trip to Indonesia, in 1982, I was surprised by how familiar everything looked. India, which I had visited nine years earlier, had seemed very exotic to me, and very different from places I knew, but in Indonesia I felt like I had been there before. Part of the familiarity as perhaps due to some of the remnants of Dutch influence: the houses in Menteng, for instance, where I spent the first nights in a guesthouse on Jln. Teuku Umar no. 66, looked very much like certain villas in the Netherlands. But the mountains and sawabs and tea plantations and forests of West Java were very unlike any Dutch landscape and yet I felt I had seen them before. And I had, of course, like all Dutchmen of my generation has: in newsreels on television, in magazines and picture books, in novels and in the cinema. 
I was born in 1946 and went to primary school in 1952. The Netherlands had only recently recognised Indonesia's Independence, but for several years we continued to use the old schoolbooks, in which some stories were set in Indonesia. My teachers spoke of the volcanos of Java, of rice and sugar cane, of wayang and gamelan, of heat and of rain. The classrooms were made more attractive with large coloured pictures hanging on the wall, that were used as teaching aids in history, biology and geography. Some of these illustrations showed scenes from life in Indonesia. This is where I saw my first volcano and my first mountain landscape with sawabs. There were also a pictures showing a wayang performance and a typical Indonesian mosque with a layered roof (atap $j o g l o$ ), and a man dressed in a white mantle and turban, looking vaguely Arab.

Another source of knowledge about Indonesia was Christian missionaries. My school was a Protestant school, and once or twice a year we were visited by missionaries who told about the conditions in such places as New Guinea (which then still was under Dutch control) and Central Sulawesi. I still remember one of them mentioning Islam: there were Muslims in their mission field (where they were only allowed to convert 'heathens') but, he said, those Muslims did not create 'problems' for them; they were faced with much more serious problems (he must have meant competition) from Catholics.

Upon Indonesia's Independence, most 'white' Dutch who had lived there, as well as many Eurasians ('Indo') and indigenous Indonesians who had worked with the Dutch Indies administration, left the country for the Netherlands, but many stayed on because they had a job or an enterprise there. Some of the tea and coffee plantations and other enterprises were still owned and run by Dutchmen, who chose to remain in Indonesia, as did of course the missionaries, some teachers and doctors, and small and big businessmen who believed they could continue to make good living in Indonesia. In 1956, at the peak of a campaign for 'Indonesianisasi', in which Dutch-owned property was nationalised, many of those Dutch and Eurasians chose (or were compelled) to flee Indonesia and resettle in the Netherlands, many of them quite impoverished. Several of these families resettled in the little town where I was growing up, and one family -a 'white' man, his Indonesian wife, and two children- became my neighbours. I do not recall them speaking much of Indonesia, but one small incident still stands out in my memory. Like many kids my age, I was a stamp Al-Jämi'ah, Vol. 53, No. 1, 2015 M/1436 H 
collector, and I had found a few Indonesian stamps (which all had Sukarno's portrait on them). Proudly I showed them to my Indonesian neighbour, expecting a few words of praise. To my surprise, she appeared deeply moved, could not take her eyes of the portrait on the stamps and cried with clear affection, 'Bung Karno, Bung Karno...' The affection that my neighbour appeared to feel for Sukarno, although she was supposedly a victim of his anti-Dutch politics, taught me that Dutch public opinion on Indonesia (which was fiercely anti-Sukarno) might be very mistaken about the attitudes of ordinary Indonesians.

A few years later I went to secondary school, where in the last years I had an excellent literature teacher, who introduced me to the greatest Dutch writers and gave me many good books to read from the school library. Looking back, I see now that many of the best books in Dutch literature had an Indonesian connection. After Multatuli's Max Havelaar, there was Couperus' Stille Kracht, Du Perron's Land van Herkomst and Haasse's Oeroeg, to mention only the most prominent ones. ${ }^{5}$ All of these novels dealt critically with the relationship between Dutch colonial settlers and the indigenous population, without however being explicitly anti-colonial. Couperus, who wrote his novel on the basis of a relatively short visit to Java, where he stayed with relatives who were colonial administrators, shows remarkable foresight. The title (The Silent Force) refers to indigenous Indonesians' inner rejection of colonial domination behind their submissive external behaviour, as well as to mysterious magical forces. The Silent Force sometimes assumes the form of a ghost-like white haji, who seems to be a symbol of the spiritual force that was ultimately going to expel the colonial power.

\section{Student Years: Anti-imperialism and Rejection of the Dutch Involvement in Indonesia}

My studies at university level had nothing to do with my later interests in Indonesia. I studied mathematics and physics, subjects that came to me easily. My original ambition was to become a nuclear physicist; later I shifted to theoretical physics, which left me more freedom and time. In the summer holidays I started travelling. My first visit to Turkey,

${ }^{5}$ Multatuli, Max Havelaar of de Koffiveilingen der Nederlandsche Handelmaatschappy, ed. by A. Kets-Vree (Amsterdam: Prometheus, 1960); Louis Couperus, De Stille Kracht (Amsterdam: Kessinger Publishing, 1900); E. Du Perron, Het Land van Herkomst, ed. by Francis Bulhof and G.J. Dorleijn (Amsterdam: Van Oorschot, 1935); Hella Serafia Haasse, Oeroeg (The Black Lake, 1948). 
In the Tradition or Outside? Reflections on Teachers and Influences

in 1966, made a great impression on me. I was fascinated by what I saw but I felt I did not understand anything of the society I found myself in. That is why I began learning Turkish and decided to take courses in anthropology, in the hope that this would help me understand Turkey better. And I continued spending six to eight weeks of every year in Turkey and the Middle East.

Like many students of my generation, I became politicised -1968 was a decisive year for us- and concerned with issues of exploitation, racism, and discrimination. I became active in several Third World solidarity movements and thought of myself as a convinced antiimperialist. The Vietnam war and the liberation movements in Southern Africa (Angola, Mozambique, South Africa) shaped our political awareness. Supporting the struggle against Apartheid in South Africa, we were aware that this was just another version of the system that had been in place in the Netherlands Indies, which made legal distinctions between Europeans, Alien Orientals, and Indigenous Indonesians.

The protests against American war crimes in Vietnam aroused memories of the Dutch conduct of war against Indonesia's Independence movement. In 1969, a television program for the first time broke the silence on war crimes committed by Dutch soldiers, featuring an interview with one former soldier who dared to speak out. The psychologist Joop Hueting spoke in detail about the cruelties he and his fellow soldiers had committed during the so-called 'police actions' (which Indonesian call, more appropriately, 'agresi militer Belanda'). A year later, two sociologists who had also been sent to Indonesia as soldiers, wrote on the basis of their own experiences an important study on what they called the derailment of violence, attempting to understand how completely ordinary, peaceful young men could in certain conditions commit the most terrible acts of violence. ${ }^{6}$ The issue caused heated controversies in the Netherlands; organisations of veterans and the largest conservative newspaper did their utmost to silence the debate on Dutch war crimes or simply denied they had taken place.

The Vietnam war forced us to reflect on the responsibility of the intellectual. American sociologists and anthropologists had been involved in counter-insurgency research both in Latin America and in Southeast Asia, which led to fierce debates in the anthropological community on the morality of serving American hegemony and harming the interests

${ }^{6}$ J.A.A. van Doorn and W.J. Hendrix, Ontsporing Van Geweld: Over Het Nederlands/Indisch/Indonesisch Conflict (Rotterdam: Universitaire Pers, 1970). 
of subjected peoples. In one of the leading journals, the anthropologists Gerald Berreman and Kathleen Gough took a clear position against such counter-insurgency involvement and pleaded for a standard of professional ethics and responsibility. ${ }^{7}$ Noam Chomsky wrote an important book on the responsibility of intellectuals, fiercely critical of the Vietnam war and the academics that took part in it that made an enormous impression on me and my friends. ${ }^{8}$ This work remains relevant and important, and I urge my younger colleagues to read it. Inspired by these debates, which had begun in America but were eagerly followed by us in Europe, the Dutch sociologist Wertheim wrote a critical article on Snouck Hurgronje's role in the Aceh War, establishing a connection between the Dutch school of Islamic studies and counter-insurgency. ${ }^{9}$

The relevance of these debates on anthropology and ethics for the case of Indonesia appeared rather obvious to us, for after having been in the vanguard of the non-aligned movement and anti-imperialist struggle for more than a decade, Indonesia had recently been brought back under Western imperialist control. The events of 1965-66, of which we came to understand the violent character only after some time, had initially fascinated me because it seemed that students played such an important role in them. Later we learned of the mass killings and understood that the students had merely been used by other forces in a bloody struggle for power (although many of the student leaders made a life-long career of this). Soon after Soeharto's takeover, the relations between the Netherlands and Indonesia were 'normalised'. Dutch companies returned to Indonesia, and international consortium for development aid (IGGI) was established, and the Netherlands became one again Indonesia's Western 'father'.

The mainstream press in the Netherlands was upbeat about the developments in Soeharto's Indonesia and remained silent on the human prize that had been paid, the hundreds of thousands who had been killed and the larger numbers of political prisoners and relatives who were deprived of basic rights. The more left-leaning media, however, reported

7 Gerald D. Berreman, "Is Anthropology Alive? Social Responsibility in Social Anthropology”, Current Anthropology, vol. 9, no. 5 (1968), pp. 391-6; Kathleen Gough, "New Proposals for Anthropologists", Current Anthropology, vol. 9, no. 5 (1968), pp. 403-7; and comments by other anthropologists on these papers, pp. 407-35.

${ }^{8}$ Noam Chomsky, American Power and the New Mandarins: Historical and Political Essays (New York: Pantheon, 1969).

9 Willem Frederik Wertheim, Counter-Insurgency Research at the Turn of the Century: Snouck Hurgronje and the Aceh War (Sociologische Gids 19/5-6, 1972), pp. 320-8. 
In the Tradition or Outside? Reflections on Teachers and Influences extensively on human rights violations in Indonesia, and provided a podium to such critics of the Soeharto regime as professors Ernst Utrecht and Wim Wertheim. There was an Indonesia solidarity committee, that published a newsletter and organised protest actions against IGGI and development aid to Jakarta. I never felt concerned enough with Indonesia to join the committee, but I read their newsletter. It must have contributed to my unwillingness to get actively involved in Indonesian studies; I did not want to be part of the new Western invasion of Indonesia.

The courses in anthropology that I followed in Utrecht were remarkably unpolitical. There were courses on the history of anthropology, on different conceptions of culture, kinship and other elements of social structure, structuralism and the anthropology of religion. The books we had to read mostly concerned Australian Aborigines, African and Indian tribal groups, and the Caribbean, but a large part of the kinship course was dedicated to Sumatran kinship systems. It was clear that Dutch anthropology owed much to the colonial relationship with Indonesia. The celebrated Leiden anthropologist J.P.B. de Josselin de Jong had developed an early and distinctly Dutch variety of structuralism based on his conception of Indonesia as a productive 'field of anthropological study' in which relatively basic common principles (in kinship, cosmology, etc.) occurred in a wide range of combinations. ${ }^{10}$ Many Dutch anthropologists of the pre-Independence generation, obviously, had carried out their most important field research in Indonesia. But in the 1950s and 1960s Indonesia had not been accessible to Dutch researchers, and that was perhaps why we read more about other parts of the world. In the years I studied anthropology, Clifford Geertz was the most influential anthropologist writing on Indonesia but I read only one or two of his articles then. Even Snouck Hurgronje, whose books on Mecca and Aceh were arguably among the most important works in the anthropology of religion ever written by a Dutch scholar, was only occasionally mentioned in passing. (I read both Geertz and Snouck Hurgronje only much later, when I was preparing my first research in Indonesia).

The most interesting lectures I remember were those by Van Baal on the anthropology of religion. ${ }^{11}$ Van Baal had studied 'Indologie,' the

${ }^{10}$ J.P.B. de Josselin de Jong, De Maleische Archipel als Ethnologisch Studieveld (Leiden: Ginsberg, 1935).

11 These lectures were later published as a book: Jan van Baal, Symbols for Communication: An Introduction to the Anthropological Study of Religion (Assen: Van Gorcum Ltd, 1971). 
courses preparing for civil service in the colonies, which then consisted of Indonesian languages, law and economics with some anthropology, in Leiden. ${ }^{12}$ He had gone on to a PhD in anthropology under De Josselin de Jong, writing a dissertation on the Marind Anim of New Guinea, before joining the civil service in Indonesia, where he held positions in Lombok, Bali and New Guinea. In his lectures he often spoke of his experiences as a colonial administrator, with a self-critical and often ironical detachment, and shared his observations of social practices in Lombok or New Guinea -but in those days I did not pay sufficient attention to those recollections of his. We students thought he was not critical enough of the colonial past, and in the days of student protest, he also was targeted, because we thought that his involvement in Dutch 'development assistance' to African and Asian countries smacked of the same old colonialism -and he responded to the protests with the same benign irony that he deployed at his own memories.

Anthropology was, for Van Baal, a method of reflection on religion and ethics, not only those of so-called 'primitive' peoples but also those of modern society and his own values and beliefs. Some of these reflections came through in his lectures, but it was only later, when he published the fruit of these 'theological' reflections (on which he had worked for almost forty years) as a book, that I began to fully appreciate his qualities as an intellectual and ethical thinker. ${ }^{13}$ There is more critical reflection and insight in his memoirs; he writes as an anthropologist of Dutch society of the early $20^{\text {th }}$ century and of the colonial service with a remarkable lucidity and detachment. ${ }^{14}$ Rereading them now, I feel proud to have been his student, but I have to admit that my awareness of his wisdom and my admiration came relatively late.

In my undergraduate days, and also when I was preparing my doctoral research, I was probably more influenced by Professor Wim Wertheim, who taught sociology in Amsterdam, than by my own teachers at Utrecht. Wertheim was a lawyer by training and had also spent the

12 On the development of 'Indologie' and the role of men like Snouck Hurgronje in giving the preparation of civil servants for the Indies and more academic character, see: Cees Fasseur Emeritus, De Indologen: Ambtenaren voor de Oost 1825-1950 (Amsterdam: B. Bakker, 1993).

${ }^{13}$ Jan van Baal, Man's Quest for Partnership: The Anthropological Foundations of Ethics and Religion (Assen: Van Gorcum, 1981).

${ }^{14}$ Jan van Baal, Ontglipt Verleden: Tot 1947, Indisch Bestuursambtenaar in V rede en Oorlog, vol. 1 (Francker: Wever, 1986); Jan van Baal, Ontglipt Verleden: Leven in Verandering 1947-1958, vol. 2 (Francker: van Wijnen, 1986). 
In the Tradition or Outside? Reflections on Teachers and Influences

early years of his career in the Netherlands Indies, as a civil servant in the judiciary there and later as a law professor in Batavia, before establishing himself as a sociologist. He had written sympathetically on the Indonesian Independence movement and the Chinese revolution, which he both saw as uprisings of the oppressed masses against their exploiters. I knew Wertheim only through the books he wrote in the early 1970s, which engaged with important bodies of social theory and were more politically relevant than much of the other sociological literature I read. ${ }^{15}$ His book on evolution and revolution was a broad overview of the academic literature on social change, revolution and counter-revolution. Whereas structural functionalism, which then still was the dominant school in anthropology, tended to focus on the positive contribution of social practices to maintaining and reproducing the social order, Wertheim gave a critical survey of the rich literature on inequality, conflict and protest, and revolutionary change. One important thing I learned from this book was that in studying a society we should look beyond the dominant or hegemonic discourse and search for what Wertheim called 'counterpoints': alternative narratives, dissident views, ways of subtly subverting the apparent consensus -the 'hidden transcripts', as James C. Scott was to call them later. ${ }^{16}$ The book on elites and masses was not only a study of social stratification but a critique of current studies and policies that had a strong elite bias and failed to understand the social dynamics because of a neglect (or fear) of the masses. In retrospect, I think that my decision to begin my studies of Indonesian Islam with observations in a poor slum, and my subsequent interest in sectarian, heretical and radical movements may have owed something to my reading of Wertheim (and similar studies) in my student days.

\section{E. First Years as an Anthropologist: the Middle East}

I finished my study of physics, worked as a teacher a few years, and decided to become an anthropologist. With the support of Van Baal, who

15 Willem Frederik Wertheim, Evolutie en Revolutie: De Golfslag der Emancipatie (Amsterdam: Kritiese Bibliotheek / Van Gennep, 1971); Willem Frederik Wertheim, Elite en Massa: Een Bijdrage tot Ontmaskering van de Elitewaan (Amsterdam: Kritiese Bibliotheek / Van Gennep, 1975); Wertheim had earlier written an important book on social change in Indonesia: Willem Frederik Wertheim, Indonesian Society in Transition: A Study of Social Change (The Hague and Bandung: Van Hoeve Ltd, 1969), but that was no part of my education, and I only was to read that in the 1980s.

${ }^{16}$ James C. Scott, Domination and the Arts of Resistance: Hidden Transcripts (New Haven: Yale University Press, 1990). 
gave my research proposal a strong endorsement, I received a research grant, which allowed me to carry out two years of field research in Kurdistan. That was perhaps the most decisive experience in my life, and I believe it changed my personality. I had been a very bookish person, not very good in socialising with other people, but the conditions of research obliged me to learn how to relate to other people and adapt myself to other cultures. For most of the time I was living in Kurdish villages and towns, as the only Westerner and without much privacy, surrounded 24 hours by people who wanted to talk to me. I had to learn Persian, Kurdish and Turkish, because these were the only languages I could communicate in with my respondents. In the course of my preparations for fieldwork, I had focused mostly on political economy, but while in the field I discovered I needed to understand more about Islam - and my Islamic education began there.

Knowing that Sufi orders (tariqa) had played an important role in the early history of Kurdish nationalism (as they had done in the Indonesian national awakening and anti-colonial struggle), I visited some influential Sufi shaykhs, and to my surprise I was allowed to stay in their houses. Shaykh Osman of Durū in Hawraman was perhaps the most prominent of the Kurdish Naqshbandi shaykhs. Originally from Iraq, he lived in a village on the Iranian side of the border, where he was visited by people from all over Kurdistan as well as Turcomans from Northeastern Iran and Arabs from Lebanon, many of whom stayed there long because they believed Shaykh Osman was a living saint. He was already an old man when I stayed with him, and I learned more from other visitors than from the man himself, although he allowed me to sit next to him when he was receiving a never-ending stream of visitors. Two other Naqshbandi shaykhs were more properly teachers. One of them, Shaykh Nurullah Varol of Cizre in Turkey, was of my own age and we rapidly became friends; the other, Shaykh Muhammad Isa, who lived mostly in Damascus, helped me with contacts among the Kurds in Syria and introduced me to the great 16th-century Kurdish Sufi poet Melayê Cizîrî. Later Shaykh Muhammad Isa was to be my guest in Utrecht. I had often stayed in people's homes during my field research; as a consequence, some of these people or their friends or relatives came to stay with me when I was back in Holland. There was no boundary between my research and private life, and I thought that was the only proper way to do anthropology.

In between my stays in different parts of Kurdistan, I regularly 
spent some time in Tehran, and later Ankara, where I found excellent libraries and bookstores to complement my interviews in the field. It was in Tehran that I started reading systematically on the history of Islam and Sufism. I also met there with some of the Western converts of the circle around Seyyed Hossein Nasr, who were deeply interested in metaphysical Sufism. I had the opportunity to attend lectures by Henri Corbin and Toshihiko Izutsu, on Ibn Arabi and other mystics. I also met other researchers in Tehran, several of whom became friends for life.

After two full years in the field, I returned to Holland. I had to hurry writing up my dissertation, for Van Baal was approaching 70, the age after which he was to lose his ius promovendi, the right to supervise dissertations. I was the last of his Dutch students, submitting my thesis in $1978 .{ }^{17}$ Later Van Baal took part in supervising one final, Indonesian dissertation, about which he told me with enthusiasm because he considered its author as a very good field worker and a genuine anthropologist. This was Alfani Daud from Banjarmasin, who submitted his thesis at the IAIN Syarif Hidayatullah in $1991 .^{18}$ Alfani thus was, in a sense, my 'brother' in anthropology; but I did not meet him until 1992 or 1993, when I visited him in Kalimantan and he took me on a tour of the sacred sites around Banjarmasin.

\section{F. Postdoctoral Researcher at KITLV}

Thus, after a few years of irregular work, I found myself as a postdoctoral researcher at the KITLV in Leiden. I had the privilege, unimaginable nowadays, of being employed for no less than four years, with no other obligation than to become an expert on Indonesian Islam. I was more or less free to choose the research I wanted to carry out, as long as it was relevant to the study of Indonesian Islam.

A senior scholar at the KITLV, Roelof Roolvink, was assigned to be my mentor and help me get acquainted with the relevant literature. Roolvink was a scholar of early Malay literature, who had written a few articles on the Sejarah Melayu and most recently a lecture on Jawi, the variety of Malay that is written in Arabic script, but had also compiled a

${ }^{17}$ Martinus van Bruinessen, "Agha, Shaikh and State On the Social and Political Structures of Kurdistan”, Dissertation (Belanda: Utrecht University, 1978).

18 The dissertation was later published as a book: Alfani Daud, Islam dan Masyarakat Banjar: Deskripsi dan Analisa Kebudayaan Banjar (Jakarta: Raja Grafindo Persada, 1997). And yes, it is an extraordinary study! 
historical atlas of the Muslim world. ${ }^{19}$ He gave useful advice on books and articles to read about the history of Islam in Southeast Asia, but where the contemporary world was concerned we soon proved to have rather different views. When I told him that I had just read Clifford Geertz's Religion of Java and really liked the book, Roolvink took a deep breath, put on a solemn expression, and told me that this was really a very bad book, so bad in fact that the KITLV had decided not to review it in its journal Bijdragen: 'Even the simple Javanese sentence in the dedication already contains a major error; the book is so full of mistakes that we found it useless to try to correct them all.' I believe it was especially the American anthropologist's scathing condemnation of Dutch colonial policies and his apparent neglect of the learned Dutch academic tradition as irrelevant, that had been the reason why Geertz was disliked in Leiden. ${ }^{20}$ Another Leiden scholar, G.W.J. Drewes, later gave me another (and more valid) reason why he objected to Geertz's work: 'He writes about the Javanese and their religion as if they are an almost illiterate people; apart from a simple guide for good behaviour he neglects all the literature that makes up their religious knowledge.' In Leiden, clearly, the preferred path to understanding Indonesian cultures was through reading manuscripts and books.

Several other persons at the KITLV provided significant help. Koos Noorduyn was the secretary general of KITLV and in that sense my direct boss. He was a specialist of Sundanese and Makassarese, and like many Dutch linguists had been trained as a Bible translator. He had lived in Bogor for a few years, improving an earlier Sundanese translation of the Old Testament, but was soon repatriated and had since been at the KITLV and concentrated on linguistic and literary studies. ${ }^{21}$ Like many others in Leiden, he looked at Indonesian societies primarily through

19 R. Roolvink, Bahasa Jawi, de Taal van Sumatra (Leiden: Universitaire Pers, 1975); R. Roolvink et al., Historical Atlas of the Muslim Peoples (Amsterdam: Djambatan, 1957).

${ }^{20}$ In The Religion of Java, Geertz briefly refers to Snouck Hurgronje's studies of Aceh and Mecca, Schrieke on the rise of Mataram in 16th-century Java, Pigeaud on wayang, Kunst on music in Java, and Gonda on Sanskrit words in Javanese. His fiercest diatribes against Dutch colonial policies, especially the cultivation system, are to be found in Clifford Geertz, Agricultural Evolution: The Process of Ecological Change in Indonesia (Berkeley: University of California Press, 1963).

${ }^{21}$ The book published in his honour upon his retirement contains a brief biography and list of his publications: D. Teljeur, Harry A. Poeze, and J.W. Schoorl (eds.), Excursies in Celebes (Leiden: KITLV, 1991). 
In the Tradition or Outside? Reflections on Teachers and Influences written texts, even though he had lived there. He knew the literature on the Islamisation of Indonesia and the spread of Islam in West Java very well, and showed some interest when I decided to do my field research in Bandung. But when I later showed him, as the Sundanese linguist, a long list of words related to sexuality, compiled in the Bandung slum where I lived (and where such words enjoyed great popularity), he was rather taken aback.

Ben Boland was professor of Indonesian Islam, when I started work at the KITLV. He had been posted in Jakarta as a missionary for most of the 1950s -I was surprised at the large number of scholars with missionary connections I met in Leiden- and he had written a book on Islam and politics in Indonesia since Independence that was not only highly informative but also surprisingly sympathetic to Muslims, especially to Masyumi. ${ }^{22}$ He had come to know personally many of the Muslim leaders who figure in his book, and I found it interesting to speak with him. He was quite sceptical of the veneration of Snouck Hurgronje that was still dominant in Leiden, and enjoyed pointing out errors of judgment by the great man. He was then preparing a historical overview of Dutch studies of Indonesian Islam, in which he highlighted the contributions of many other scholars whose work had received less attention that that of Snouck and his students but nonetheless was of great value. It was published as the introductory essay to his bibliography of Indonesian Islam, which has remained an important resource for me through the years. $^{23}$

Kees van Dijk then worked in the Department of Documentation on Modern Indonesia and regularly wrote overviews of recent developments in Indonesia in the journal RIMA (Review of Indonesian and Malayian Affairs). He had also just completed his dissertation on the Darul Islam movement. ${ }^{24}$ Kees was one of the few in Leiden who were interested in contemporary developments in Indonesia. He had studied sociology in Rotterdam and his dissertation had been supervised by the anthropologist P.E. de Josselin de Jong in Leiden, but like his surveys of recent developments, it was exclusively based on newspapers and other written materials, without any interviews with participants or

22 B.J. Boland, The Struggle of Islam in Modern Indonesia (The Hague: Martinus Nijhoff, 1971).

23 Boland and Farjon, Islam in Indonesia.

${ }^{24}$ C. van Dijk, Rebellion Under the Banner of Islam: The Darul Islam in Indonesia (The Hague: Martinus Nijhoff, 1981). 
opponents. In that sense it was a typical product of Leiden, where (I gathered) armchair anthropology, philology and detailed narrative history were preferred over adventurous fieldwork. But the book was highly appreciated by Indonesians; I remember a long conversation with a Soeharto opponent, several years later, who asked me to convey his thanks to Van Dijk for writing such an important study, which confirmed his conviction that the santri were the only social force in Indonesia that would be capable of bringing about regime change. Several of my later friends pointed out errors in the book that were due to bias in the sources, but they too were otherwise very positive about the book. Van Dijk himself, who succeeded Boland as professor of Indonesian Islam in 1986, meanwhile continued working in the same way, carefully reading the Indonesian press and other written materials. He did visit Indonesia regularly but never had the desire to interview people or make direct observations.

One other colleague to whom I owed much during those years of my initiation into Indonesian studies was not affiliated with the KITLV but was then teaching at the IAIN Syarif Hidayatullah in Jakarta. I mean of course Karel Steenbrink. I had first heard about him from Van Baal, who praised him for having carried out fieldwork in a pesantren in East Java. For his dissertation on Islamic education in Indonesia, ${ }^{25}$ Steenbrink had not only read Indonesian source materials and interviewed people but he had actually lived in a pesantren, like one of the santri, and later he had somehow ended up as the only Western lecturer at a Indonesia's most prestigious institute of Islamic education. Not long after my appointment at the KITLV, I received a letter from Steenbrink, who welcomed me as a new colleague in the field and warmly invited me to his home when I would visit Indonesia. I found Karel and his family living on the IAIN campus, happy to be in everyday contact with Karel's colleagues and students (unlike other expats, who lived in upper middle class districts and had few relations with Indonesians). The Steenbrink residence in Ciputat, and later in Yogyakarta, became like a second home, where I would often spend a few days. Conversations with Karel were an important part of my education as an Indonesianist. Karel was in those days concentrating on the 19th century, and he was systematically exploring the National

${ }^{25}$ Karel A. Steenbrink, "Pesantren, Madrasah, Sekolah: Recente Ontwikkelingen in Indonesisch Islamonderricht", Dissertation (Belanda: Katholieke Universiteit te Nijmegen, 1974); translated into Indonesian as Karel A. Steenbrink, Pesantren, Madrasah, Sekolah: Pendidikan Islam dalam Kurun Modern (Jakarta: LP3ES, 1986). 
In the Tradition or Outside? Reflections on Teachers and Influences

Archives for material on Islamic movements in that period (as Sartono Kartodirdjo had done before). He also stimulated his students to do archival research, giving an important impulse to historical studies at the IAIN. ${ }^{26}$ The historical sections of my article on kitab kuning and my book on the Naqshbandiyya no doubt owe much to my conversations with Karel.

\section{G. Preparing Fieldwork in Indonesia}

The idea of becoming yet another typical Leiden scholar did not appeal to me. I like reading, and I have always read a lot, but I was convinced that original new research needed fieldwork rather than extensive library study. Moreover, I planned to return to Turkey and Kurdistan after my Indonesian intermezzo, and therefore was not inclined to invest too much time and energy in reading all the writings of those men from Leiden. Therefore I thought of a comparative study on social processes that took place in Indonesia as well as the Middle East, and one obvious process to look at was the rise of radical Islam.

I had been in Iran during the Islamic Revolution and I had observed the rise of political Islam in Turkey (in fact, I was still finishing a few articles about both when I started working at the KITLV), and I had been reading on the rise of radical Islam in Egypt. Theories trying to explain the rise of Islamic radicalism typically were varieties of the relative deprivation thesis applied to migrants from villages and small towns to large cities, who failed to be integrated economically in city life. Relative deprivation has been proposed as an explanation of a wide range of phenomena, from millenarian movements to mass strikes and social revolutions. ${ }^{27}$ The thesis claims that people are spurred into action when they perceive that the quality of their lives deteriorates compared to that of others or compared to what they had come to expect. Many revolutions took place when after a period of increasing welfare the expected economic halted and a period of decline set in -as was the case in Iran after 1977. Studies looking at Islamic radicals pointed out that many of them had migrated from villages and small towns to large

${ }_{26}$ The book on $19^{\text {th }}$-century Islam that he published in Indonesian is in fact not only a useful overview but also a guide for further research: Karel A. Steenbrink, Beberapa Aspek tentang Islam di Indonesia Abad ke-19 (Jakarta: Bulan Bintang, 1984).

27 Ted Robert Gurr, Why Men Rebel (New York: Princeton University Press, 1970); Sylvia L. Thrupp, Millennial Dreams in Action: Essays in Comparative Study (The Hague: Mouton, 1962). 
cities in search of education and work, had initially experienced some improvement in their lives but found their rising expectations frustrated. Feeling rejected by the older urban middle classes, whose 'secular' lifestyle violated many traditional religious norms, they expressed their frustration in religious terms. ${ }^{28}$

The weakness of the relative deprivation thesis is that it appears to be able to explain almost everything. Among the causes of every rebellion or revolutionary movement it may be possible to find some form of relative deprivation - but it is quite likely that many other people who did not rebel were equally deprived. Instead of first focusing on radicals and asking to what extent relative deprivation lay at the roots of their radicalism, I thought it should be interesting to look at people who actually experienced intense relative deprivation and observe whether their sense of deprivation was expressed in radicalism or otherwise. After two trips to Java and Sumatra for orientation and studying the migration literature, I chose Bandung as the site for my research, because it did not have the ethnic complexity of Jakarta, Surabaya and Medan -most migrants to Bandung were Sundanese, with a smaller number of Central Javanese and hardly any others- and because it was also known as a hotbed of radicalism: Imran's group had recently gained international notoriety by hijacking a Garuda plane. ${ }^{29}$

One of the conditions for receiving a research permit in Indonesia was to find an Indonesian scholar willing to act as my counterpart. At the suggestion of Koos Noorduyn and LIPI's Edi Masinambouw, I approached the Sundanese historian Edi S. Ekadjati, who also had a Leiden connection. This proved to be a very fortunate choice; Pak Edi was a highly-respected person in Bandung, and he appeared to know almost everyone in the world of learning and the arts there. He was a lecturer at Universitas Padjadjaran and soon after my arrival became the head of the newly established Institute for Sundanese Studies, Lembaga Sundanologi. Through him I met many budayawan who were willing to share their vast knowledge of Sundanese culture and Sundanese

${ }^{28}$ The classical study of this type is: Saad Eddin Ibrahim, "Anatomy of Egypt's Militant Islamic Groups: Methodological Note and Preliminary Findings”, International Journal of Middle East Studies, vol. 12, no. 04 (1980), pp. 423-53; I later made a comparison of the Egyptian, Turkish and Iranian cases in Martin van Bruinessen, "Muslim Fundamentalism: Something to be Understood or to be Explained Away?", Islam and Christian-Muslim Relations, vol. 6, no. 2 (1995), pp. 157-71. 1984).

29 Anjar Any, Dari Cicendo ke Meja Hijau: Imran Imam Jamaah (Solo: CV Mayasari, 
In the Tradition or Outside? Reflections on Teachers and Influences

kebatinan with me. Two of them I should like to single out here: Pak Ema Bratakusuma, an aristocrat and local Maecenas, who cultivated a syncretistic Sundanese spiritual tradition believed to be derived from the ancient Hindu kingdom of Galuh, and Pak Oemar Soeraatmadja, who had been a Muslim politician in the early years of the Republic. Pak Oemar had been the secretary-general of the Bandung branch of the Muslim party Masyumi as well as a leading activist of the puritan Muslim association Persis, but had become a Sufi teacher adhering to a syncretistic cult, after which he had been expelled from Masyumi and Persis.

I located a poor urban kampung in which most inhabitants were immigrants to Bandung and had faced repeated adversity and failure. It was perhaps the poorest kampong of Bandung and definitely the most densely inhabited one. This was the research site I was looking for, so I rented a little house and decided to live there for a year. I needed one or two assistants, and asked Karel Steenbrink if he could suggest an IAIN student who might want to work with me. Karel and his wife Paule introduced me to Lies Marcoes, who had done interesting fieldwork in a pesantren tarekat in Tasikmalaya and who was the only student they knew who was passionately interested in anthropological research. I had several other assistants during my research, but Lies alone had the endurance to live in the squalid neighbourhood where we lived for almost a year. Lies was more than an assistant; in many ways she became my teacher -of Indonesian and Sundanese language and culture, of how to communicate respectfully with our neighbours- and research partner. Our first report on the research in the poor kampung, Sukapakir, we wrote together. ${ }^{30}$

\section{H. Shifts of Attention: from Political Economy to Mysticism and Popular Piety}

Life in Sukapakir was again an experience that deeply affected me; and in spite of many difficulties, I was quite happy there. But my observations and interviews drew me into another direction than I had expected. It became clear very soon that the poor in my neighbourhood were not at all drawn to radicalism, or to Islamic piety for that matter. There was a small community of Persis followers, who gave each other strong mutual support and made an effort to stay separate from their

30 This report was published as a supplement ('Selingan') in the weekly Tempo, 27 Oktober 1984. This and my other articles and reports on life in Sukapakir are reprinted in Martin van Bruinessen, Rakyat Kecil, Islam dan Politike (Yogyakarta: Gading, 2013). 
immediate environment, which they perceived as sinful and immoral. Some of the women took part in pengajian, religious lessons given once or twice per week in private homes, which provided rare opportunities for respectable social interaction. Many were not at all religious, and to the extent that they were, it was magic and syncretistic mysticism that held sway over them rather than orthodox Islam. In my neighbours' life histories, all the political and social upheavals of the preceding half century played a part, as well as religious movements that appealed especially to the poor. I became fascinated by the Sundanese kebatinan movements -Sunda Wiwitan, Perjalanan/Permai, Moeslimin Moeslimat, Abduljabbar, and others- most of which had followers among my neighbours and that were especially strong in the rural districts around the city. There were several dukun among my neighbours; I learned what they were willing to share of their knowledge of magic (elmu) and visited sacred sites in Cirebon with one of them.

I also discovered that the Naqshbandi and Qadiri Sufi orders had a presence in Bandung and West Java in general. In a bookstore I found by chance a copy of a Naqshbandi compendium written by a Kurdish author, Muhammad Amin al-Kurdi's Tanwìr al-Qulüb, which was the first of many accidental discoveries that made me look for the connection between Kurdish and Indonesian Islam. I visited Abah Anom, the charismatic shaykh of the Tarekat Qadiriyah wan Naqsyabandiyah, in his village Suryalaya and discovered that there was in fact a Pondok Inabah, one of his centres for Sufi healing of various types of disorders, close to the neighbourhood where I lived. A religious teacher living nearby took me one Thursday to Banten to receive the blessings of another charismatic Qadiri shaykh, Ki Armin.

Some researchers choose their object of research, and in the case of others it may be the object that chooses the researcher. The latter undoubtedly was my case: numerous accidental observations and meetings drew me towards the mystical traditions of Indonesia. I gave up the idea of immediately returning to Turkey and Kurdistan after my four years at the KITLV. When an opportunity to return to Indonesia and continue studies on its Islamic traditions offered itself, I immediately accepted. I received an invitation that was too interesting to turn down: the Indonesian Institute of Sciences, LIPI, was preparing a large research project on the worldview of Indonesia's ulama, and I was invited to join the project and train the Indonesian researchers in fieldwork and interview methods. Pak Mochtar Buchori, who was in charge, knew of 
In the Tradition or Outside? Reflections on Teachers and Influences my research in Sukapakir and wanted LIPI's researchers to carry out equally intensive fieldwork.

\section{At LIPI: Focus on Ulama, Muslim Intellectuals, Kitab Kuning and Religious Study Groups}

The format of LIPI's research project was decided before I arrived, in September 1986. To prevent the usual Java-centred bias, all provinces with a Muslim majority population (and in some cases regions within a large province) were to be studied separately. There were to be two researchers for each province, one from LIPI and the other from a local university, who were supposed to make an inventory of the Muslim associations, movements and institutions and identify a number of representative ulama for further investigation. Through interview and observation they were to derive conclusions about the ulama's world view, their social teachings and their attitudes. My task was to help these researchers reflect on what we meant by world view and attitude, and on ways to infer those from sermons, writings, and interviews. The project gave me a unique opportunity to visit almost all of Indonesia's Musliminhabited regions, for I accompanied the researchers to the field, took part in some of their interviews, and helped them to collect other relevant information. Their networks of contacts were extremely useful for my own research. I began two projects of my own, which were directly related to the ulama project. Wherever I went, I looked for toko kitab and collected the books in Arabic script that were used in the pesantren, dayah, surau and madrasa of that region. And I always enquired if there were Naqshbandi shaykhs in the region, and then looked them up and interviewed them. Without the help of the researchers in this project and the ulama who were its objects, I would never have been able to write my overviews of kitab kuning and the Naqshbandiyah. ${ }^{31}$

It was a true privilege to work with the local researchers, who

31 Martin van Bruinessen, "Kitab Kuning: Books in Arabic Script Used in the Pesantren Milieu", Bijdragen tot de Taal-, Land-en Volkenkunde (BKI), vol. 146, no. 2-3 (1990), pp. 226-69; Martin van Bruinessen, "The Origins and Development of the Naqshbandi Order in Indonesia”, Der Islam, vol. 67, no. 1 (1990), pp. 150-79; Martin van Bruinessen, Tarekat Naqsyabandiyah di Indonesia. Survei Historis, Geografis dan Sosiologis (Bandung: Mizan, 1992); The kitab kuning I collected, more than a thousand titles, are deposited in the KITLV library (which is now integrated in the Leiden University Library). 
were among the best scholars of their region, such as Rusydi Sufi in Aceh, Usman Pelly in Medan, Sanusi Lathief in Padang, UU Hamidy in Pekanbaru, Abdullah Fadjar in Yogyakarta, Analiansyah in Banjarmasin, Muchlis and Ahmad Rahman in Ujung Pandang (Makassar) -I have learned a lot, and gained important insights, from each of them. My interactions with the Jakarta-based scholars involved in the project were even more intensive, and most of them remained friends well after the project was over: Moeslim Abdurrahman, Masdar F. Mas'udi, Wardah Hafidz, Wiladi Budiharga, Lies Marcoes, 'Pangcu' Driyantono, Syamsuddin Haris, Bisri Effendi, Erwiza Erman, Mahrus Irsyam. Several of them were or became NGO activists, involved in efforts to empower marginalised groups, and made important contributions to progressive Muslim discourse in Indonesia. ${ }^{32}$

Moreover, three prominent Muslim intellectuals -Nurcholish Madjid, Abdurrahman Wahid and Djohan Effendi- were involved in the research project as consultants. In the course of the project, we got to know each other well and became friends. I felt extremely fortunate: these were the most interesting Muslim thinkers of Indonesia, of whom I had read and heard much and whom I had wanted to get to know since I had started working in Indonesia, and now we were working together as colleagues.

It was thanks to Gur Dur that I was invited into the world of NU and the pesantren. With his letters on introduction, all doors opened for me. When he became interested in my observations on the Naqshbandiyya, on the Kurdish influences I thought I observed here and there in Indonesia, and in the collection of kitab kuning that I was compiling, we gradually became closer. He is perhaps the person to whom I feel most indebted here in Indonesia. He stimulated me to continue my research on the pesantren, kitab kuning and tarekat, promising to write a preface for the book I planned, ${ }^{33}$ and he was one of my authorities -although I soon learned it was better to double-check everything he said. His claims were

32 I write of these 'transformative' discursive and NGO activities in: Martin van Bruinessen, "Liberal and Progressive Voices in Indonesian Islam", in Reformist Voices of Islam: Mediating Islam and Modernity, ed. by Shireen T. Hunter (New York: M.E. Sharpe, 2008), pp. 187-207. And Martin van Bruinessen, "What happened to the smiling face of Indonesian Islam? Muslim Intellectualism and the Conservative turn in post-Suharto Indonesia”, RSIS Working Papers, vol. 222 (Singapore: S. Rajaratnam School of International Studies, 2011).

33 See Abdurrahman Wahid's preface in Martin van Bruinessen, Kitab Kuning, Pesantren dan Tarekat: Tradisi-tradisi Islam di Indonesia (Bandung: Mizan, 1994), pp. 11-4. 
In the Tradition or Outside? Reflections on Teachers and Influences usually interesting but not always literally correct.

Djohan Effendi was more soft-spoken but I soon learned it was worthwhile to pay attention to everything he said; Djohan had an enormous range of learning, which he generously shared with me. Djohan was a teacher and mentor to many younger people; it was much easier to approach him than Nurcholish or Gus Dur; he was more patient, and more mindful of what young learners need. As the experienced head of the research desk of the Ministry of Religious Affairs, he was an inexhaustible source of information on all sorts of Islamic movements and Sufi orders. Djohan had been a close friend of the late HMI activist and journalist Ahmad Wahib and was (together with Ismed Natsir) the editor of Wahib's diaries, which provocatively challenged the established patters of Islamic thought and gave their numerous young readers a strong impulse to thing independently and critically. ${ }^{34}$ But he also worked at the State Secretariat, where he wrote most of Soeharto's speeches on religious subjects. He was never apologetic about writing for Soeharto; he always simply wrote what he thought was right, never anything he did not mean. Whatever we may hold against Soeharto, the official discourse on religion in his days was highly tolerant and inclusive, and I believe this was at least in part due to Djohan.

Nurcholish was of course the prima donna among the Muslim intellectuals, but he was also a genuinely very modest person. He had recently returned from Chicago, where he had written a $\mathrm{PhD}$ thesis under Fazlur Rahman's supervision. He was formally a lecturer at the IAIN and a researcher at LIPI, and he spent much time delivering invited lectures throughout the country. In order to give him a platform from which he could reach influential sections of the Jakartan middle class, Dawam Rahardjo and other friends organised a 'religious study club' they named Paramadina. Each month there was one guest speaker, followed by a complementary talk by Nurcholish himself. I followed these Paramadina pengajian regularly. Later I was also invited a few times to take part in the famous Wednesday evening discussion meetings, when the core members of the 'religious renewal' (pembaruan

34 Ahmad Wahib, Pergolakan Pemikiran Islam: Catatan Harian Abmad Wabib, ed. by Djohan Effendi and Ismed Natsir (Jakarta: LP3ES, 1981). For a discussion of this influential book, see Anthony H. Johns, "An Islamic System or Islamic Values? Nucleus of a Debate in Contemporary Indonesia", in Islam and the Political Economy of Meaning: Comparative Studies of Muslim Discourse, ed. by William R. Roff (London: Croom Helm, 1987), pp. 254-80. 
pemikiran Islam) movement met. Towards the end of the decade, Alwi Shihab organised a small closed study group with the most important established and emerging progressive Muslim thinkers of the period (called Empati), where besides Nurcholish, Djohan and Abdurrahman, the regular participants included Quraish Shihab, Utomo Danandjaja, Aswab Mahasin, Moeslim Abdurrahman and Masdar Mas'udi, Haidar Bagir and Agus Abu Bakar. The discussions, introduced by a wellprepared introduction by one of the members, were about topics such as ijma $^{-6}$ tafsir, sunna. To be able to attend those discussions was like following a private course in critical Islamic studies, which I experienced as very stimulating. ${ }^{35}$

My years at LIPI also saw the flourishing of a wide variety of Muslim NGOs, in which several of my colleagues and friends were involved. Among the NGOs that I frequently visited were Lakpesdam, the NGO established by NU to carry out the social programs that its 1984 Congress in Situbondo had set as one of its tasks; P3M, a pesantren-based NGO, not strictly NU-affiliated, which carried out various pesantren-based community development projects; and LSAF (Institute for the Study of Religion and Philosophy), a 'discourse NGO,' established by Dawam Rahardjo, that aimed to introduce a more sophisticated religious discourse to the modernist Muslim middle class. Masdar Mas'udi was a staff member of P3M and later became its director. He also edited a journal called Pesantren, and this is where I published some of the first articles based on my research on Indonesian Islamic traditions. ${ }^{36}$ Another publication with which I proudly associated myself was the very interesting journal Ulumul Qur'an that LSAF published from 1989 onwards, and for which I wrote several articles. ${ }^{37}$ I remained

${ }^{35}$ My own contribution was made together with Nasir Tamara, who was a great admirer of Mohammed Arkoun. Together we tried to translate a part of his book on the Qur'an (Lectures du Coran, Paris: Maisonneuve \& Larose, 1982) into Indonesian, and I attempted to explain the ideas explored there in my talk at Empati. Mohammed Arkoun, Lectures du Coran (Paris: Maisonneuve \& Larose, 1982).

36 Martin van Bruinessen, "Bukankah Orang Kurdi yang Mengislamkan Indonesia?", Pesantren, vol. 4, no. 4 (1987), pp. 43-53; Martin van Bruinessen, "Kitab Fiqh di Pesantren Indonesia dan Malaysia”, Pesantren, vol. 1, no. 5 (1989), pp. 36-51.

37 Martin van Bruinessen, "Tarekat Qadiriyah dan Ilmu Syaikh Abdul Qadir Jilani di India, Kurdistan, dan Indonesia”, Ulumul Qur'an, vol. 2, no. 2 (1989), pp. 68-77; Martin van Bruinessen, "Mencari Ilmu dan Pahala di Tanah Suci: Orang Nusantara Naik Haji”, Ulumul Qur'an, vol. 2, no. 5 (1990), pp. 42-49; Martin van Bruinessen, "Gerakan Sempalan di Kalangan Umat Islam Indonesia: Latar Belakang Sosial-Budaya”, Ulumul Qur'an, vol. 3, no. 5 (1992), pp. 16-27. 
In the Tradition or Outside? Reflections on Teachers and Influences

in contact with both LSAF and P3M in the 1990s, especially with Masdar, who authored an interesting book on social justice based on a reinterpretation of the prescriptions concerning zakat, and organised a series of discussion meetings (halaqah) with kiai on contemporary social and political issues, challenging them to make their understanding of religion relevant to the modern world. ${ }^{38}$

In Jakarta too I lived in a simple house in a kampung, not far from the LIPI office, so that I could go to work on foot. I was the only foreigner in the wide neighbourhood, and had no contact with other expats; all my friends were Indonesian (with the exception of my colleague Jaap Erkelens, the KITLV representative in Indonesia). The only other 'white' person whom I often saw, and who became a close friend, was the human rights lawyer Poncke Princen (or Haji Princen, as most Indonesians knew him), but he was of course also an Indonesian by nationality. He had been sent to Indonesia as a soldier at the time of the military operations against the Independence movement but had chosen the side of the Republic and joined the ranks of the Siliwangi division -for which he was rewarded with a bintang gerilya decoration. He had been a member of parliament in the 1950s but also a political prisoner under both Sukarno and Soeharto. As a human rights activists, he had defended radical Muslims as well as labour activists. ${ }^{39}$

In the LIPI project, we had avoided the radicals, expecting that they would distrust LIPI anyway because it is a government institution and knowing that publicising their worldview would only incriminate them. But since beginning my first fieldwork in Bandung, I had remained curious to understand the roots of radical Islam; and I was convinced that a serious study of Islam in Indonesia also needed to take the radicals into account. Through my friendship with Poncke, I could enter different social worlds and meet victims of the New Order's human rights violations, including radical Muslim activists fiercely opposed to the Soeharto regime. Poncke even managed to get me into prison to speak to the imprisoned activist A.M. Fatwa.

${ }^{38}$ Masdar Farid Masudi, Agama Keadilan: Risalah Zakat (Pajak) dalam Islam (Jakarta: Pustaka Firdaus, 1991). On the halqah that Masdar organised with the support of open-minded senior kiai such as Sahal Mahfudh, Imron Hamzah and Wahid Zaini, see Martin van Bruinessen, NU: Tradisi, Relasi-Relasi Kuasa, Pencarian Wacana Baru (Yogyakarta: LKiS, 1994), pp. 220-34.

39 The journalist Joyce van Fenema helped Poncke write his autobiography: Joyce van Fenema, Een Kwestie van Kiezen (The Hague: BZZTôH, 1995). Translated as Kemerdekaan Memilib: Otobiografi Poncke Princen, Jakarta: Hasta Mitra, 1995). 
This reminds me of another dear friend and as remarkable a person as Poncke: Alijah Gordon, a scholar-activist who was the founder and current director of the Malaysian Sociological Research Institute in Kuala Lumpur -which was rather a small NGO but had published a number of important books. Alijah was originally American but had become a Malaysian and was deeply involved in various solidarity movements. She organised humanitarian support for Palestine, and had good relations with many progressive and Islamic social movements. In her youth, she had written a thesis on the Kurds, and that was probably one of the reasons why we got along well the first time that we met. Whenever I passed through Kuala Lumpur, I went to see her. Aware that some of Indonesia's radicals were at that time living in exile in Malaysia, I asked if she could help me meet them. Thus I could make some interviews that proved very useful to my understanding of the underground N.I.I. (Negara Islam Indonesia) networks. ${ }^{40}$

LIPI's ulama project took less than two years until completion, but I remained at LIPI and took part in another large project dealing with co-operatives in various parts of the country, while continuing to focus on ulama and Muslim discourses. A summary of my own conclusions from the ulama research project appeared in the English version of the journal Prisma, which was published by the earliest major NGO in New Order Indonesia, LP3ES, which had also been the first to explore the potential of the pesantren for grassroots development. In the article I looked specifically at the political attitudes of ulama and Muslim intellectuals and I attempted to explain what I understood to be the dilemma faced by many ulama who disagreed with policies of the Soeharto regime but did not have the courage to openly criticise it. ${ }^{41}$

${ }^{40}$ I wrote my first article on radical Islam, in which I highlighted the role of Indonesia's State Intelligence Agency in 'Islamic' violence under a pseudonym because I did not want to implicate LIPI, where I was then working: Chris Baers: "Heilige Oorlog, Sociaal Protest of Provokatie? Indonesische Moslims en Politiek Geweld" ("Holy War, Social Protest or Provocation? Indonesian Muslims and Political Violence"), in C. van Dijk (ed.), Islam en Politiek in Indonesië (Muiderberg: Coutinho, 1988), pp. 51-68. The interviews in Malaysia proved especially useful for an article I wrote much later under my own name: Martin van Bruinessen, "Genealogies of Islamic Radicalism in Post-Suharto Indonesia”, South East Asia Research, vol. 10, no. 2 (2002), pp. 117-54.

${ }^{41}$ Martin van Bruinessen, "Indonesia's Ulama and Politics: Caught between Legitimising the Status Quo and Searching for Alternatives", Prisma, no. 49 (1990), pp. 52-69. 
In the Tradition or Outside? Reflections on Teachers and Influences

\section{J. Teaching at IAIN Sunan Kalijaga}

My posting at LIPI ended in mid-1990 and I returned to the Netherlands, with enough material for years of writing books and articles. A few weeks after my arrival, however, Saddam Hussein invaded Kuwait, initiating a chain of responses that led to a large Kurdish uprising in the following spring. My attention was soon focused on the Middle East and the role of the Kurds in the developing crisis. As one of the few experts on the Kurds, I was often invited to speak at public meetings and conferences; I collected information and wrote about the genocide of Iraqi Kurds that Saddam had committed in 1988, with chemical weapons and mass executions killing at least 50,000 and perhaps many more; and in the spring of 1991, when millions of Kurds, fearing another offensive with chemical arms, had fled to the Turkish and Iranian borders, I offered my services as a translator to the humanitarian NGO, Doctors without Borders, that was bringing relief to the displaced people on the Iraqi-Turkish border. I spent around six weeks in Turkey and Northern Iraq.

Meanwhile, however, I had received another invitation that was to bring me back to Indonesia. The Leiden-based program INIS (Indonesian-Netherlands Co-operation in Islamic Studies) brought Indonesian MA students to Leiden and placed two Dutch lecturers at the IAINs of Jakarta and Yogyakarta. (At both institutions, these were therefore replacements of Karel Steenbrink, who had been teaching there before). Johan Meuleman and Herman Beck had started teaching in Jakarta and Yogyakarta in 1989; when Beck found a good job in the Netherlands and announced he would leave Yogya in 1991, the INIS co-ordinator, Wim Stokhof, asked if I was willing to take over in Yogya for a few years. I answered, 'yes, if I can go to Kurdistan first,' and so I ended up in Yogya, where I lived for the next two and a half years. I taught sociology and anthropology of religion, research methods, and Orientalism in the Postgraduate (Pascasarjana) program, and comparative religion in the Fakultas Ushuluddin. Apart from anthropology of religion, I had not formally studied those subjects myself, but I knew that the best way to learn about a subject is by teaching it or writing a book about it, for this obliges you to systematically read the relevant literature. And that is what I did; I had brought many books with me and read voraciously in preparation of my lectures.

My students came from all over Indonesia, and most wanted to 
write about their own region. I tried to help them find the right method for an original paper or thesis, and profited in turn from their knowledge of local traditions. In class too, I tried to make use of the available local knowledge. Several of the books and articles that I wrote in the following years were a direct product of my teaching, and my students often contributed material to those writings. Teaching the course on Orientalism was perhaps most difficult. I tried to convey the main ideas of Edward Said's book on Orientalism as a European discourse of power and domination, but I also wanted my students to acquaint themselves with the writings of important academic Orientalists. I read some of Snouck Hurgronje's works with them, as well as Goldziher and Juynboll on hadith and isnäd and their interpretations of how obviously false hadiths had been put into circulation, but this was a subject many students found difficult to discuss rationally.

Of my colleagues at the IAIN, I was excited to get to know Mukti Ali, whom I knew to have played an important role in stimulating Muslim intellectualism. He had officially retired but he continued organising the irregular seminar with speakers from outside, which had been a famous venue for free exchange of ideas. I had only a few long conversations with him, about his experiences as the New Order's first Minister of Religious Affairs, about his conception of a Sufism without tarekat, his views of kebatinan and how it could be domesticated, and his views of inter-religious dialogue. Another colleague whom I had wanted to meet was Simuh, an expert on Sufism and Javanese mysticism, whose dissertation on Ronggowarsito I had read and liked. Unfortunately, we never got beyond polite smiles and friendly words; Pak Simuh appeared very introverted and the opposite of talkative. I had more contacts with Mahasin and Malik Madani, who were both active in NU. Mahasin impressed me, on the occasion of a guest lecture by Mohammed Arkoun, by posing a question in French, a language he had learned by himself in order to read literature for his dissertation. Another colleague who impressed me was Amin Abdullah, with whom I could speak Turkish, because he had obtained a doctorate from Turkey. The lecturer I had most contact with in Yogyakarta, however, and whose work I liked very much was the historian Kuntowijoyo, who taught at UGM.

Besides my own students, I had much contact with various NGO and student activists, who often would visit me at home or invite me to discussions elsewhere in town. Yogyakarta was, in the Soeharto years, an important centre of student activism and critical discussions. I sensed 82

Al-Jämíah, Vol. 53, No. 1, 2015 M/1436 H 
an eagerness for ideas that were different from the New Order's official discourse, and a curiosity for all the forbidden ideas, from Liberation Theology and Marxism to radical Islamism. I found it striking that most of the students who visited me at home had a NU background -perhaps they saw me as someone close to NU because of my good relations with Abdurrahman Wahid, whom I continued seeing, or because I continued writing about traditionalist Islam and pesantren culture, or because I did not hide my scepticism about ICMI. (The only Muhammadiyah activist whom I saw more or less regularly was Rusli Karim, besides of course Moeslim Abdurrahman and my colleague Amin Abdullah, but they all belonged to an older generation than the activist students.)

I frequently met with the group of activists that was later to become LKiS, and our histories have become connected. In 1994, LKiS published my book on NU, helping to make me a well-known person in NU circles. ${ }^{42}$ After my years in Yogya I stayed in contact with them; I liked them especially because they combined an interest in progressive Islamic discourse -one of my interests- with social and political activities. Especially during the late Suharto years, they were among the most interesting action groups around; their training was politically relevant and very trendy: it seemed that everyone who was young and ambitious wanted to take part. One of the LKiS activists, Farid Wajidi, later joined me in the Netherlands, where he became a junior research fellow at ISIM and was actively involved in international NGO networks of a similar kind.

Other student activists who became friends and with whom I have stayed in contact included Cholidy Ibhar and Ciciek Farha. Cholidy was for some time my assistant and accompanied me on several trips to Madura and East Java (he was Madurese himself, and was strongly marked by pesantren culture). Later he settled in Kebumen, where he became a kiai (initially under the shadow of his father-in-law) and later also a PKB politician. Ciciek was, along with Farid Wajidi, active in inter-religious dialogue and later increasingly in women's rights activism. This was the time when the controversial idea of Muslim feminism or Islamic feminism began to be discussed in Indonesia, and I am proud that several of my friends played a pioneering part in it. Wardah Hafidz discovered an interesting text on "women's theology" by the Pakistani feminist theologian Riffat Hassan, which she translated and published

42 Bruinessen, NU. 
in Ulumul Qur'an, sparking a heated debate. ${ }^{43}$ Later Wardah invited Riffat Hassan to visit Indonesia for a series of talks and discussions (including one at the IAIN, which I could arrange, and another one with Ciciek and NGO activists in Yogya), which made quite an impact. ${ }^{44}$ Lies MarcoesNatsir, who had joined P3M, brought the idea of women's rights into that NGO's efforts to make religious discourse more sensitive to the social and political context. The proceedings of a workshop on women and religious scripture that she organised were another pioneering publication (in which I had a contribution too). ${ }^{45}$ Lies was to be involved with most of the Islamic women's NGOs of the following years, and she is now no doubt the most experienced person in this field. Ciciek too was for many years one of the most prominent Muslim women's activists, leading the NGO Rahima in Jakarta and training numerous younger women.

\section{K. Inserting Myself into the Scholarly Tradition(s)}

I had been proud to be an outsider in Leiden, and I had been able to carry out my research among the poor in Bandung without mastering the existing literature on Islam in Indonesia, but for a project on the worldview of Indonesian ulama there was no excuse: I had to study what had been written by earlier scholars of Islamic learning, the ulama and religious authority in Indonesia. In fact, I had already started reading more or less systematically all I could find on Sufism and syncretistic mysticism in Indonesia when my fieldwork in Bandung brought up these phenomena as significant. Teaching in Yogyakarta obliged me to present the scholarly tradition in a coherent way, which meant I needed to read much and also reflect on my own position towards the various schools in the learned tradition. Boland's overview and bibliography proved a very useful guide to explore this tradition. ${ }^{46}$

Although I had initially some doubts about Snouck Hurgronje and the adoration he enjoyed in Leiden, fed by criticism of his role in

43 Riffat Hassan, "Teologi Perempuan dalam Tradisi Islam", Ulumul Qur'an, vol. 1, no. 4 (1990), pp. 48-55. The next issue of Ulumul Qur'an contained a number of responses to Hassan's arguments.

${ }^{44}$ See Wardah Hafidz' interview with Riffat Hassan: "Feminisme dan AlQur'an: Wawancara dengan Riffat Hassan”, Ulumul Qur'an, vol. 3, no. 5 (1994).

${ }^{45}$ Lies M. Marcoes-Natsir and Johan H. Meuleman (eds.), Wanita Islam Indonesia dalam Kajian Tekstual dan Kontekstual: Kumpulan Makalab Seminar (Jakarta: INIS, 1993).

46 Boland and Farjon, Islam in Indonesia. 
In the Tradition or Outside? Reflections on Teachers and Influences

the Aceh war and his methods, ${ }^{47}$ I came to find his books, articles and the numerous reports he wrote as adviser to the Government essential sources for my own work. His study of daily life in Mecca (as observed in 1885) remains unsurpassed, and so I know of no more comprehensive study of any ethnic group in Indonesia than his two volumes on the Acehnese. ${ }^{48} \mathrm{I}$ used both works extensively for my own research on the ulama, kitab kuning and Sufi orders. His collected articles and his counsels as adviser to the government also remain highly valuable as a resource on the social history of Indonesia in the late colonial period. ${ }^{49}$ Although much of the information in his books was in fact collected for him by collaborators, whom he does not give sufficient credit, he was clearly an excellent field researcher himself. During his years in Batavia, he did not live like other Europeans there but was known to live in 'indigenous' style (and married with local women, daughters of ulama), which no doubt facilitated his contacts with Indonesians. His Arabic was recognised as excellent, and he knew several Indonesian languages - he published linguistic studies about Acehnese syntax and about remarkable aspects of the Arabic spoken by the Hadramis.

Snouck Hurgronje could be scathing about his colleagues, and he heaped scorn on his predecessor as government advisor on Islam in Batavia and professor of Arabic and Islam in Leiden, L.W.C. van den Berg, whose book on the principles of Islamic law, he argued, was very theoretical and took no account of actual practices in the Indies. Or rather, he considered the local legal practices as 'deviations' from Islamic law, instead of realising that the practice of Islamic law is everywhere embedded in adat, local custom. ${ }^{50}$ In fact, Van den Berg was quite aware of Shafi i fiqh as it was studied and practised in Java and Madura, and besides a major book on fiqh he also wrote a number

47 Wertheim, Counter-Insurgency Research; P. Sj. van Koningsveld, Snouck Hurgronje's "Tzhaar oel-Islaam”: Een Veronachtzaamd Aspect van de Koloniale Geschiedenis (Leiden: Faculteit der Godgeleerdheid, 1893).

${ }^{48}$ Christiaan Snouck Hurgronje, Mekeka, Bd.II: Aus Dem Heutigen Leben (Haag: Nijhoff, 1889), translated into English as Christiaan Snouck Hurgronje, Mekeka in the Latter Part of the 19 $9^{\text {th }}$ Century (Leiden: Brill, 1931); Christiaan Snouck Hurgronje, De Atjèhers, vol. 2 (Batavia: Landsdrukkerij, 1893).

49 Christiaan Snouck Hurgronje, Verspreide Geschiften (Collected articles), vol. I-V Bonn/Leipzig, 1923-1925; vol. VI, Brill: Leiden, 1927; Cornelis Adriaanse and E. Gobée (eds.), Ambtelijke Adviezen van C. Snouck Hurgronje, 1889-1936, Eerste dell, vol. 3 ('s-Gravenhage: Martinus Nijhoff, 1957).

${ }^{50}$ Christiaan Snouck Hurgronje, 'Mr. L.W.C. van den Berg's Beoefening van Het Mohammedaansche Recht', Verspreide Geschriften II, pp. 59-222. 
of important studies about the pesantren tradition, and a major study of Hadramawt and the Hadrami communities of Indonesia (as well as the first ever article on the Naqshbandiyya in Indonesia). ${ }^{51}$ He deserves not to be forgotten.

Snouck collected numerous manuscripts, which are now in the Leiden University Library, and which were later edited and analysed by his students and later generations of Leiden scholars. Rinkes, Djajadiningrat, Schrieke, Kraemer, Pijper, Drewes, Doorenbos, Zoetmulder, Edel, and Van Nieuwenhuijs wrote dissertations on important manuscripts, mostly by Sufi authors, in the Leiden collection. ${ }^{52}$ Of these dissertations, I found those by Djajadiningrat and Zoetmulder by far the most interesting, but Rinkes, Schrieke and Pijper were the ones whose later work had the greatest impact on my own.

Hoesein Djajadiningrat was one of the young Indonesian aristocrats whom Snouck had adopted and coached to prove the validity of his theory of association, namely that Indonesians were capable of the same intellectual development as 'white' Dutchmen (he was still thinking of men, not women). Djajadiningrat proved his mentor right:

51 L.W.C. van den Berg, De Beginselen van het Mohammedaansche Recht, volgens de Imam's Aboe Hanîfat en asj-Sjâfe î̀ (Batavia: Ernst/'s Gravenhage, 1874); L.W.C. van den Berg, "De Mohammedaansche Geestelijkheid en de Geestelijke Goederen op Java en Madoera", Tijdschrift voor Indische Taal-, Land- en Volkenkunde, vol. 27 (1882), pp. 1-46; L.W.C. van den Berg, "Het Mohammedaansche Godsdienstonderwijs op Java en Madoera en de Daarbij Gebruikte Arabische boeken", Tijdschrift voor Indische Taal-, Land- en Volkenkunde, vol. 31 (1886), pp. 519-55; L.W.C. van den Berg, Le Hadhramout et Les Colonies Arabes Dans l'Archipel Indien (Batavia: Imprimerie du Gouvernement, 1886); L.W.C. van den Berg, "Over de Devotie der Naqsjibendijah in den Indischen Archipel”, Tijdschrift voor Indische Taal-, Land-en Volkenkunde, vol. 31 (1883), pp. 158-75.

${ }^{52}$ D.A. Rinkes, "Abdoerraoef van Singkel: Bijdrage tot de kennis van de mystiek op Sumatra en Java”, Ph.D Thesis (Leiden, 1909); Hoesein Djajadiningrat, "Critische Beschouwing van de Sadjarah Banten”, Ph.D Thesis (Haarlem: Leiden University, 1913); B.J.O. Schrieke, "Het boek van Bonang", Ph.D Thesis (Haarlem: Leiden University, 1916); H. Kraemer, "Een Javaansche Primbon Uit de Zestiende Eeuw”, Ph.D Thesis (Leiden: Leiden University, 1921); G. Pijper, "Het Boek der Duizend Vragen”, Ph.D Thesis (Haarlem: Leiden University, 1924); Gerardus Willebrordus Joannes Drewes, "Drie Javaansche Goeroe's: hun leven, onderricht en messiasprediking", Ph.D Thesis (Leiden: Leiden University, 1925); Johan Doorenbos, "De Geschriften van Hamzah Pansoeri”, Ph.D Thesis (Leiden: Leiden University, 1933); Petrus J. Zoetmulder, "Pantheïsme en Monisme in de Javaansche Soeloek-Literatuur", Ph.D Thesis (Leiden: Leiden University, 1935); Jan Edel, "Hikajat Hasanoeddin", Ph.D Thesis (Meppel: Utrecht University, 1938); Christoffel Anthonie Olivier van Nieuwenhuijze, "Samsu 'l-Dīn van Pasai: bijdrage tot de kennis der Sumatraansche mystiek", Ph.D Thesis (Leiden: Leiden University, 1945). 
In the Tradition or Outside? Reflections on Teachers and Influences

his dissertation, and also his other writings, are if anything superior to most other work of the Leiden school. He was appointed professor at the Batavia Law School (the precursor of Universitas Indonesia) in 1924, was head of the Bureau of Religious Affairs during the Japanese occupation, in 1948 Minister of Education of the Republic of Indonesia, and from 1952 onwards professor of literatures at Universitas Indonesia.

Zoetmulder was also rather different from the other Leiden scholars. He was 'white' but a Catholic and a Jesuit. His own wish had be to study mathematics, but his Jesuit superiors decided that he should study Javanese and sent him to Leiden. His dissertation concerned the monistic mysticism (the doctrine of manunggaling kawula gusti) in 18thcentury Javanese suluk texts. Later he taught himself Old Javanese, of which he became the leading scholar in the world. He spent most of his life in Indonesia, and lived in Yogya when I taught there. He seemed to recognise much of his own religious ideas in Javanese mysticism (he showed me a poem by himself, which to my ear sounded pantheistic though he claimed it was not) and perhaps he imposed too much of his own interpretation on the texts, but his dissertation remains the most important study of Javanese mysticism that I know -besides some of the work by Merle Ricklefs and Simuh. ${ }^{53}$

Douwe Rinkes had a career in the Bureau of Indigenous Affairs and the Department of Education, and was involved in efforts to 'tame' the Sarekat Islam. ${ }^{54}$ Before he became a full-time adviser and bureaucrat, however, he continued the research he had begun in his dissertation on Abdurra'uf and the Shattariyya with a number of interesting articles on the saints of Java, beginning with Abdul Muhyi of Pamijahan and continuing with Seh Siti Jenar, Sunan Geseng, Sunan Bayat and Pangeran Panggung. ${ }^{55}$ It was perhaps because two of the most

${ }^{53}$ Merle Ricklefs also recognised this as a study of lasting importance and translated it into English: P.J. Zoetmulder, Pantheism and Monism in Javanese Suluk Literature (Leiden: KITLV Press, 1994).

${ }^{54}$ For a critical view of Rinkes' attitude towards nationalist Indonesians, see Doris Jedamski, "Balai Pustaka: A Colonial Wolf in Sheep's Clothing”, Archipel, vol. 44, no. 1 (1992), pp. 23-46; for a more positive view, see G.W... Drewes, "D.A. Rinkes; A note on his life and work (Met portret)", Bijdragen tot de Taal-, Land-en Volkenkunde (BKI), vol. 117, no. 4 (1961), pp. 417-35.

55 Originally published in Dutch in the Tijdschrift voor Indische Taal-, Land-en Volkenkunde between 1910 and 1913, these studies were translated into English as: Douwe Adolf Rinkes, Nine Saints of Java, ed. by Alijah Gordon, trans. by H.M. Froger (Kuala Lumpur: Malaysian Sociological Research Institute, 1996). 
memorable experiences of my very first trip to Indonesia had been my visits to the shrines of Abdul Muhyi in Pamijahan and Sunan Gunung Jati in Cirebon that I from early on felt attracted to these studies by Rinkes, apparently based on Javanese manuscripts and perhaps local tradition. (It is unsatisfactory that Rinkes says nothing of his sources; but his studies contain information that I have never found anywhere else.)

As a scholar, however, I felt much closer to B.J.O. Schrieke, whose work is much more sociological in nature, and often based on the man's own direct observations, although he had also primarily been trained as a philologist. Schrieke worked a few years (1920-23) in the Bureau for Indigenous Affairs, and then became professor of Sociology and Anthropology at the Batavia Law School. He was a tireless traveller, had many Indonesian friend, and wrote on a wide range of subjects. To him we owe an insightful study on the debates between Islamic reformists and traditionalists in West Sumatra in the early 20th century, and another one on Communism in the same region, analysing the roots of the 1927 uprising, but he also wrote on discussions in the Arabic press, circumcision practices all over the Archipelago, and the political economy of the Archipelago in the $16^{\text {th }}-17^{\text {th }}$ centuries, the period of the rise of the Muslim kingdoms. ${ }^{56}$

It comes as no surprise that Wertheim often refers to Schrieke in his own historical studies. ${ }^{57}$ So does Harry J. Benda in his excellent book on Indonesian Islam under the Japanese occupation. ${ }^{58}$ (Benda was only indirectly part of the Dutch tradition of Indonesian studies; born in a Prague Jewish family, he escaped to Indonesia when Hitler occupied

56 Bertram Johannes Otto Schrieke, "Bijdrage tot de Bibliografie van de Huidige Godsdienstige Beweging ter Sumatra's Westkust”, Tijdschrift voor Indische Taal-, Land- en Volkenkunde, vol. 59 (1920), pp. 249-325; Johannes Otto Schrieke Schrieke, "De Strijd Onder de Arabieren in Pers en Literatuur", Notulen van het ... Bataviaasch Genootschap, vol. 58 (1921), pp. 189-240; Bertram Johannes Otto Schrieke, "Allerlei over de besnijdenis in den Indischen Archipel", Tijdschrift voor Indische Taal-, Land- en Volkenkunde, vol. 61 (1922), pp. 373-578; Bertram Johannes Otto Schrieke, "Allerlei over de besnijdenis in den Indischen Archipel", Tijdschrift voor Indische Taal-, Land- en Volkenkunde, vol. 60 (1921), pp. 1-94.. His studies of communism in West Sumatra and the historical studies are reprinted in his two-volume Indonesian Sociological Studies. Selected writings, The Hague: Van Hoeve, 1955-57.

57 Wertheim, Indonesian Society in Transition; Willem Frederik Wertheim, Indonesië van Vorstenrijk tot Neo-Kolonie (Meppel: Boom, 1978).

${ }_{58}$ Harry J. Benda, The Crescent and the Rising Sun: Indonesian Islam under the Japanese Occupation 1942-1945 (The Hague: W. van Hoeve, 1958). 
In the Tradition or Outside? Reflections on Teachers and Influences

Czechoslovakia. He was in contact with Dutch scholars there, and after the war studied in New Zealand and the USA, receiving his PhD from Cornell and teaching at Yale.) Schrieke, Benda and Wertheim are the most perceptive authors on the role of Islam as a social and political factor in the long-term processes of change affecting Indonesian society.

G.F. Pijper was the last of the Advisers for Indigenous Affairs and a professor of Arabic in Batavia and later Amsterdam. He did not write much, but every single article he wrote was very well researched. His studies are very detailed and show impressive knowledge and understanding as well as empathy; but they remain, as the title of his first book rightly affirms, brilliant fragments that do not add up to a coherent overall view. ${ }^{59}$ He never attempted a synthesis or explanation of the social dynamics of Islam in Indonesia. His work is highly descriptive, and in this sense represents the best of the Dutch tradition as well as the general reluctance of Leiden Orientalists to engage in theoretical analysis. Like Snouck Hurgronje before him, Pijper established warm and friendly relations with several ulama -in his case especially reformists: Ahmad Soorkati, whom he appears to have considered as a teacher, A. Hassan of Bandung, and Basyuni Imran in Sambas. In terms of perceptiveness and understanding of the issues, Pijper's article on Islamic reform in Indonesia is probably still the best I have read. ${ }^{60} \mathrm{He}$ also wrote on the Tijaniyya and the Ahmadiyah, on mosques and minaret architecture, on the rituals of the middle of the month of Sha 'ban, the last Wednesday of Safar, and the Miraj. And he was also the first of the Dutch Islamologists with a clear gender awareness, writing about women's mosques and debates on monogamy, and observing how his friend Soorkati continued taking financial responsibility for his divorced wife. $^{61}$

59 Guillaume Frédéric Pijper, "De Vrouw en de Moskee", in Fragmenta Islamica (Leiden: Brill, 1934); Guillaume Frédéric Pijper, Studiën Over de Geschiedenis van de Islam in Indonesia 1900-1950 (Leiden: Brill, 1977); both books were translated into Indonesian by his student and successor as professor of Arabic at Universitas Indonesia, Tudjimah. Guillaume Frédéric Pijper, Fragmenta Islamica: Beberapa Studi Mengenai Sejarah Islam di Indonesia Abad XX, trans. by Tudjimah (Jakarta: Penerbit Universitas Indonesia, 1987).

${ }^{60}$ Guillaume Frédéric Pijper, "Het Reformisme in de Indonesische Islam", in Studiën Over de Geschiedenis van de Islam in Indonesia 1900-1950 (Leiden: Brill, 1977), pp. 97-145.

${ }^{61}$ Pijper, "De Vrouw en de Moskee", pp. 1-58; Guillaume Frédéric Pijper, "De Strijd om de Monogamie", Koloniale Studiën, vol. 21 (1937), pp. 476-190; Pijper, "Het Reformisme". 
These were the men of the Leiden school from whom I learned much, although I never met them. My own work, from around 1990 onwards, is indebted to theirs. But there were others. The leading historian of Indonesian Islam, Merle Ricklefs, though an American based in Australia, is also close to the Leiden tradition (and especially to the Dutch Javanists Pigeaud and De Graaf). I had liked his early article on the Islamisation of Indonesia, ${ }^{62}$ and when I was trying to rewrite the history of the pesantren, I wrote to him for advice. This was the beginning of a long friendship, in the course of which we often discussed our ongoing research with each other. Of all Merle's books, the ones closest to my own interests are his study of 'the seen and unseen worlds' of 18th-century Java, in which he shows convincingly the strong interconnection of mysticism and political power in Mataram, as well as his book on the origins of the abangan-santri dichotomy in the second half of the 19 th century. ${ }^{63}$

Two other Australian scholars with whom I have much interacted were Lance Castles and Herb Feith. I first met Lance when we both worked in Jakarta (he was then at UI), and later during my years in Yogya he also was there, teaching at UGM. Lance's study on santri entrepreneurship in Kudus and his article on the modern pesantren of Gontor were pioneering works that remain important. Lance as well as Herb Feith had spent much time in Indonesia from the 1950s onwards and closely followed political developments. Lance had worked in Aceh, leading an institute for training in the social sciences, and was very close to the Acehnese. He was especially interested in religion and very knowledgeable about Islam; I discovered that he knew large sections of the Qur'an by heart. Lance always was my most critical reader, always willing to challenge my interpretations. While I was mostly focusing on the NU and traditionalist Islam during those years, my discussions with him persuaded me to keep following the radical undercurrents as well.

There were yet other foreign colleagues who had a considerable influence on my work. The French scholar Denys Lombard, whose work on Aceh in the time of Iskandar Muda I had read, was a man

${ }^{62}$ Merle Calvin Ricklefs, "Six centuries of Islamization in Java", in Conversion to Islam, ed. by Nehemia Levtzion (New York: Holmes \& Meier Pub, 1978), pp. 100-28.

${ }^{63}$ Merle Calvin Ricklefs, The Seen and Unseen Worlds in Java, 1726-1749: History, Literature, and Islam in the Court of Pakubuwana II (Honolulu: University of Hawaii Press, 1998); Merle Calvin Ricklefs, Polarising Javanese Society: Islamic and Other Visions (c. 18301930) (Singapore: NUS Press, 2007). 
In the Tradition or Outside? Reflections on Teachers and Influences

with a broad vision, who attempted to emulate in Nusantara Braudel's historiography of the longue durée. He was working on his ambitious three-volume book on Java in the perspective of global history when we met, and I found our discussions unvaryingly stimulating. ${ }^{64}$ One of his interests concerned the Chinese influences in Javanese and other regional cultures; together with his wife, the Sinologist Claudine Salmon, he had written on the much-neglected subject of Chinese influences in Indonesian Islam. ${ }^{65}$ That was a subject that has long fascinated me, especially since visiting the grave complexes of Sunan Gunung Jati, Sunan Bonang, Sunan Drajat, and Sunan Giri, and reading Parlindungan's controversial Tuanku Rao and the alleged Chinese chronicle of the Wali Sanga. ${ }^{66}$

Lombard was one of the godfathers of the group around the journal Archipel, which I found in many ways more interesting than Leiden's own Bijdragen, because they had a broader range of interests and did not neglect aspects of everyday life for which Leiden scholars had little time. In fact, I believe it was because I had reviewed the two special issues of Archipel dedicated to Indonesian Islam in 1985 that I first came to meet members of the group -Claude Guillot, Marcel Bonneff, Pierre Labrousse, Henri Chambert-Loir, and later Andrée Feillard- each of whom has made some important contributions to Indonesian studies. The French style of scholarship is quite different from the somewhat stiff and pedantic Dutch tradition, and I felt much at ease with them.

There was another French circle in which I became involved, also based at the École des Hautes Études en Sciences Sociales in Paris: a group of students of Sufism and Sufi orders, who organised large conferences where they invited everyone who had ever written anything worth reading about a specific tarekat. I joined their conference on the

${ }^{64}$ Denys Lombard and Ecole francaise d'Extreme-Orient, Le Sultanat d'Atjeh au Temps d'Iskandar Muda (1607-1636) (Paris: Ecole Francaise d'Extreme-Orient, 1967); Denys Lombard, Le Carrefour Javanais: Essai d'histoire Globale, vol. 3, de l'EHESS edition (Paris: Ecole Hautes Etude en Sciences Sociales, 1990).

${ }_{65}$ Denys Lombard, "Islam et Sinité”, Archipel, vol. 30, no. 1 (1985), pp. 73-94.

${ }^{66}$ Mangaradja Onggang Parlindungan, Pongkinangolngolan Sinambela gelar Tuanku Rao: Terror Agama Islam Mą̧ab Hambali di Tanab Batak 1861-1833 (Djakarta: Tandjung Pengharapan, 1964); the chronicle was edited and translated by M.C. Ricklefs (ed.), Hermanus Johannes de Graaf and Theodore G. Th Pigeaud (trans.), Chinese Muslims in Java in the 15th and 16th Centuries: The Malay Annals of Semarang and Cerbon (Clayton: Monash University, 1984). 
Naqshbandiyya, where I met many colleagues who became helpful friends, and I was part of several of their later efforts on the Qadiriyya, the Bektashiyya and other orders. The central figures of the group were Alexandre Popovic, Marc Gaborieau, and the younger Thierry Zarcone. The latter founded the Journal of the History of Sufism, of which I was to become a regular contributor. ${ }^{67}$ In this circle I met the great scholar Michel Chodkiewicz, a leading expert on Ibn Arabi and someone very close to the Naqshbandiyya. When I was working on my book on the Naqshbandiyya, I sent him my chapters and he wrote me his very valuable comments, with corrections and suggestions for more literature. It was also due to my contacts with this group that I made an effort to absorb the knowledge accumulated in the tradition of Indonesian Sufi studies - my one deliberate attempt to place myself in the tradition. The article I wrote on the subject was first presented at one of the conference at which the two French networks met. ${ }^{68}$

While in Jakarta I became acquainted with, and learned much from, the Cornell anthropologist James Siegel, who had written beautiful but difficult books on Islam in Aceh and on Solo in the New Order and who was doing new research in Jakarta. ${ }^{69}$ An anthropologist working close to the grassroots, as I believed anthropologists should, an unconventional man and a sharp observer; strolling through Jakarta with him was always a voyage of discovery. People in Aceh had told me how they had seen him and his wife working in the paddy fields while they were doing their research there in the 1960s. Jim was also into French poststructuralist authors, who influenced his way of looking, and I suppose I became more appreciative of this style of thought

${ }^{67}$ Martin van Bruinessen, "Shaykh 'Abd al-Qādir al-Jīlānī and the Qādiriyya in Indonesia", Journal of the History of Sufism, vol. 1, no. 1 (2000), pp. 361-95; Martin van Bruinessen, "After the Days of Abû Qubays: Indonesian Transformations of the Naqshbandiyya-Khâlidiyya", Journal of the History of Sufism, vol. 5 (2008), pp. 225-51.

${ }_{68}$ Martin van Bruinessen, "Studies of Sufism and the Sufi Orders in Indonesia", Die Welt des Islams, vol. 38, no. 2 (1998), pp. 192-219. One of the conclusions is, that these studies were until c. 1955 dominated by Dutch scholars writing in Dutch, that between 1955 and 1975 English was the dominating language (and the type of studies also changed), whereas from 1975 onwards more and more studies in Indonesian begin appearing. For 1976-1995 period, the bibliography lists 5 studies in Dutch, 35 in English, 7 in German, 2 in French, and 80 in Indonesian.

${ }^{69}$ James T. Siegel, The Rope of God (Berkeley: University of California Press, 1969; revised and expanded in new edition: The Rope of God (Ann Arbor: University of Michigan Press, 2000); James T. Siegel, Solo in the New Order: Language and Hierarchy in an Indonesian City (Princeton: Princeton University Press, 1993). 
In the Tradition or Outside? Reflections on Teachers and Influences because of him.

\section{Back to the Netherlands: ISIM and Other International Networks}

I returned to the Netherlands in 1994 to take up a position as a lecturer of Turkish and Kurdish language, culture and history at Utrecht University. A few years later, four universities established ISIM, the International Institute for the Study of Islam in the Modern World, and I became the Utrecht-based professor at ISIM. This gave me the possibility to organize numerous international seminars and conferences, to invite interesting people, and to supervise students from many countries. Our first academic director was Muhammad Khalid Masud, an important progressive Muslim scholar and thinker. We had intensive contacts, and it was a privilege to work with such a learned man.

The reason for establishing ISIM was that university administrators then thought that the 'traditional' approaches to Islamic studies failed to take account of important developments in the world of Islam. At ISIM we attempted to create a meeting place of people coming from different intellectual traditions. We wanted interdisciplinary studies, combining different approaches, but social science approaches were dominant in the research that we supported. Philology, the central discipline of the Leiden school, was for us not an aim in itself but an often necessary tool: we wanted our young researchers to have a good command of the relevant languages and of the texts written in those languages; but we wanted them to study living Islam, not only its texts. We also wanted an exchange between critical Muslim thinkers and scholars of Islam, for which my Indonesian experience was useful, and we organised several workshops with Muslim intellectuals from countries such as Iran, Turkey, India, Indonesia, Sudan, Tunisia, South Africa, North America and Europe.

Unlike my teaching at Utrecht, which was entirely concerned with the Middle East, ISIM allowed me to continue supervising research on Indonesia as well as carrying out research of my own. I am very proud of the Ph.D. students and their dissertations on various aspects of Islam in Indonesia -all of them to do with various types of Islamic 
movements rather than classical Islamic studies. ${ }^{70} \mathrm{~A}$ program on Islam and civil society that I led at ISIM also involved the study of and cooperation with NGOs, both 'discourse' NGOs and advocacy and development NGOs, as well as Sufi orders as a form of civil society. ${ }^{71}$ My own research of this period focused mostly on the changes of the post-Soeharto period, with an emphasis on political Islam, and owes much to my Indonesian students and collaborators. ${ }^{72}$

\section{The End of the Leiden School?}

The Leiden school -the departments of Indonesian languages and cultures and of Islamic studies, and the KITLV - had long been facing a declining interest by Dutch students of the younger generation. It could survive (at least in part) because of the projects that brought Indonesian students to Leiden for MA and PhD studies. The program that provided me with my initial postdoctoral fellowship had been intended to stimulate the emergence of a younger generation of Indonesian experts so that the rich resources in the Netherlands (libraries and collections, archives) would be matched by human expertise. The decline of societal interest in Indonesian matters has continued, however, and Leiden University little by little dismantled its once impressive departments of Indonesian and Islamic studies. The chair of Indonesian Islam was discontinued

${ }^{70}$ Noorhaidi, "Laskar Jihad: Islam, Militancy and the Quest for Identity in Post-New Order Indonesia", Ph.D. Thesis (Belanda: Utrecht University, 2005); Mujiburrahman, "Feeling Threatened: Muslim-Christian Relations in Indonesia's New Order", Ph.D. Thesis (Amsterdam: Utrecht University, 2006); Syuan Yuan Chiou, "In Search of New Social and Spiritual Space: Heritage, Conversion, and Identity of Chinese-Indonesian Muslims", Ph.D. Thesis (Utrecht: Utrecht University, 2012); Hilman Latief, Islamic Charities And Social Activism Welfare, Dakwah And Politics In Indonesia (2012); Din Wahid, "Nurturing the Salafi Manhaj: A Study of Salafi Pesantrens in Contemporary Indonesia", Ph.D. Thesis (Utrecht: Utrecht University, 2014).

${ }^{71}$ Farid Wajidi, "Syarikat dan Eksperimentasi Rekonsiliasi Kulturalnya (Sebuah Pengamatan Awal)", Tashwirul Afkar, vol. 15 (2003), pp. 55-79; Martin van Bruinessen and Farid Wajidi, "Syu'un Ijtima'iyah and the Kiai Rakyat: Traditionalist Islam, Civil Society and Social Concerns", in Indonesian Transitions: Work in Progress, ed. by Henk Schulte Nordholt and Ireen Hoogenboom (Yogyakarta: Pustaka Pelajar, 2006), pp. 205-48; Martin van Bruinessen and Julia Day Howell, Sufism and the "Modern" in Islam (London: I.B.Tauris, 2007).

${ }^{72}$ The third section of my Rakyat Kecil, Islam dan Politik contains most of my writing on Indonesia of that period. One of the last research projects I directed at LIPI involved Moch. Noer Ichwan, Mujiburrahman, Ahmad Najib Burhani, and M. Wildan and resulted in a collective volume: Martin van Bruinessen (ed.), Contemporary Developments in Indonesian Islam: Explaining the "Conservative Turn” (Singapore: ISEAS, 2013). 
In the Tradition or Outside? Reflections on Teachers and Influences

after Kees van Dijk's retirement. The one remaining leading expert in Leiden is Nico Kaptein, who has supervised more Indonesian students than anyone else but is not a professor himself. ${ }^{73}$ We find a few other representatives of the Leiden tradition dispersed over the world. Edwin Wieringa, the best philologist of his generation to graduate from Leiden, teaches in Frankfurt am Main in Germany. Merle Ricklefs and Stuart Robson, who to some extent represented the tradition in Australia, are retired now and I do not think anyone there replaces them. Two younger historians with a strong interest in philology, however, Michael Feener at the National University of Singapore and Michael Laffan at Princeton University, have absorbed much of the work of the Leiden school into their own. ${ }^{74}$

ISIM existed for ten years and then fell victim to inter-university rivalries. The networks which it helped to establish continue to be active, however. The Centre for Modern Oriental Studies (ZMO) in Berlin (where I am the chairman of the advisory board) continues ISIM's approach, and colleagues who did their $\mathrm{PhDs}$ or postdoctoral work at ISIM are present in many of the best academic institutions in Europe and the Muslim world. The Muslim feminist network Musawa, too, owes something to ISIM and appropriately Khalid Masud is one of its active supporters. I am proud to see the Indonesians who were once connected with ISIM - my PhD students but others as wellplaying an active role in stimulating scholarship and intellectual debate in Indonesia. It is their turn now, and I wish them much success!

${ }^{73}$ Kaptein recently published his magnum opus, on a subject close to the Leiden tradition: Nico J.G. Kaptein, Islam, Colonialism and the Modern Age in the Netherlands East Indies: A Biography of Sayyid Uthman (1822 - 1914) (Leiden: Brill Academic Publishers, 2014).

${ }^{74}$ Laffan spent three years in Leiden as a post-doctoral researcher, studying the Indonesian collections of the University Library, in preparation of a book that is at once a study of the history of Sufism in Indonesia and of the way the Leiden school of Orientalism shaped our knowledge of it: Michael F. Laffan, The Makings of Indonesian Islam: Orientalism and the Narration of a Sufi Past (New York: Princeton University Press, 2011). Feener spent much of his time in Singapore studying developments in Aceh. His recent book on Aceh can be seen as a successor to Snouck's study, both in subject and scope: R. Michael Feener, Sharia and Social Engineering: The Implementation of Islamic Law in Contemporary Aceh, Indonesia (Oxford: Oxford University Press, 2013). 


\section{BIBLIOGRAPHY}

Adriaanse, Cornelis and E. Gobée (eds.), Ambtelijke Adviezen van C. Snouck Hurgronje, 1889-1936, Eerste dell, vol. 3, 's-Gravenhage: Martinus Nijhoff, 1957.

Any, Anjar, Dari Cicendo ke Meja Hijau: Imran Imam Jamaah, Solo: CV. Mayasari, 1984.

Arkoun, Mohammed, Lectures du Coran, Paris: Maisonneuve \& Larose, 1982.

Baal, Jan van, Symbols for Communication: An Introduction to the Anthropological Study of Religion, Assen: Van Gorcum Ltd, 1971.

----, Man's Quest for Partnership: The Anthropological Foundations of Ethics and Religion, Assen: Van Gorcum, 1981.

----, Ontglipt Verleden: Tot 1947, Indisch Bestuursambtenaar in V rede en Oorlog, vol. 1, Francker: Wever, 1986.

----, Ontglipt Verleden: Leven in Verandering 1947-1958, vol. 2, Francker: van Wijnen, 1986.

Benda, Harry J., The Crescent and the Rising Sun: Indonesian Islam under the Japanese Occupation 1942-1945, The Hague: W. van Hoeve, 1958.

Berg, L.W.C. van den, De Beginselen van het Mohammedaansche Recht, volgens de Imam's Aboe Hanîfat en asj-Sjâfe 'r, Batavia: Ernst/'s Gravenhage, 1874.

Berg, L.W.C. van den, "De Mohammedaansche Geestelijkheid en de Geestelijke Goederen op Java en Madoera", Tijdschrift voor Indische Taal-, Land-en Volkenkunde, vol. 27, 1882.

----, "Over de Devotie der Naqsjibendijah in den Indischen Archipel", Tijdschrift voor Indische Taal-, Land- en Volkenkunde, vol. 31, 1883, pp. 158-75.

----, "Het Mohammedaansche Godsdienstonderwijs op Java en Madoera en de Daarbij Gebruikte Arabische boeken", Tijdschrift voor Indische Taal-, Land-en Volkenkunde, vol. 31, 1886.

----, Le Hadhramout et Les Colonies Arabes Dans l'Archipel Indien, Batavia: Imprimerie du Gouvernement, 1886.

Berreman, Gerald D., "Is Anthropology Alive? Social Responsibility in Social Anthropology", Current Anthropology, vol. 9, no. 5, 1968, pp. 391-6 [http://dx.doi.org/10.1086/200923].

Boland, B.J., The Struggle of Islam in Modern Indonesia, The Hague: Martinus 
In the Tradition or Outside? Reflections on Teachers and Influences Nijhoff, 1971.

Boland, B.J. and I. Farjon, Islam in Indonesia: A Bibliographical Survey, 1600-1942 with Post-1945 Addenda, Dordrecht: Foris Publications Holland, 1983.

Bruinessen, Martin van, "Agha, Shaikh and State On the Social and Political Structures of Kurdistan", PhD Thesis, Utrecht : Utrecht University, 1978.

----, "Bukankah Orang Kurdi yang Mengislamkan Indonesia?”, Pesantren, vol. 4, no. 4, 1987.

----, "Kitab Fiqh di Pesantren Indonesia dan Malaysia", Pesantren, vol. 1, no. 5, 1989 .

----, "Tarekat Qadiriyah dan Ilmu Syaikh Abdul Qadir Jilani di India, Kurdistan, dan Indonesia”, Ulumul Qur'an, vol. 2, no. 2, 1989.

----, "Kitab Kuning: Books in Arabic Script Used in the Pesantren Milieu", Bijdragen tot de Taal-, Land-en Volkenkunde (BKI), vol. 146, no. 2-3, 1990, pp. 226-69 [http://dx.doi.org/10.1163/22134379-90003218].

----, "The Origins and Development of the Naqshbandi Order in Indonesia”, Der Islam, vol. 67, no. 1, 1990, pp. 150-79.

----, "Mencari Ilmu dan Pahala di Tanah Suci: Orang Nusantara Naik Haji”, Ulumul Qur'an, vol. 2, no. 5, 1990.

----, 'Indonesia's Ulama and Politics: Caught between Legitimising the Status Quo and Searching for Alternatives”, Prisma, no. 49, 1990.

----, Tarekat Naqsyabandiyah di Indonesia. Survei Historis, Geografis dan Sosiologis, Bandung: Mizan, 1992.

----, "Gerakan Sempalan di Kalangan Umat Islam Indonesia: Latar Belakang Sosial-Budaya", Ulumul Qur'an, vol. 3, no. 5, 1992.

----, Kitab Kuning, Pesantren dan Tarekat: Tradisi-tradisi Islam di Indonesia, Bandung: Mizan, 1994.

----, NU: Tradisi, Relasi-Relasi Kuasa, Pencarian Wacana Baru, Yogyakarta: LKiS, 1994.

----, "Muslim Fundamentalism: Something to be Understood or to be Explained Away?", Islam and Christian-Muslim Relations, vol. 6, no. 2, 1995, pp. 157-71 [http://dx.doi.org/10.1080/09596419508721050].

----, "Studies of Sufism and the Sufi Orders in Indonesia", Die Welt des Islams, vol. 38, no. 2, 1998, pp. 192-219 [http://dx.doi. org/10.1163/1570060981254813]. 
----, "Shaykh 'Abd al-Qâdir al-Jîlânî and the Qâdiriyya in Indonesia", Journal of the History of Sufism, vol. 1, no. 1, 2000, pp. 361-95.

----, "Genealogies of Islamic Radicalism in Post-Suharto Indonesia", South East Asia Research, vol. 10, no. 2, 2002, pp. 117-54 [http:// dx.doi.org/10.5367/000000002101297035].

----, "After the Days of Abû Qubays: Indonesian Transformations of the Naqshbandiyya-Khâlidiyya", Journal of the History of Sufism, vol. 5, 2008, pp. 225-51.

----, "Liberal and Progressive Voices in Indonesian Islam", in Reformist Voices of Islam: Mediating Islam and Modernity, ed. by Shireen T. Hunter, New York: M.E. Sharpe, 2008.

----, "What happened to the smiling face of Indonesian Islam? Muslim Intellectualism and the Conservative turn in post-Suharto Indonesia”, RSIS Working Papers, vol. 222, Singapore: S. Rajaratnam School of International Studies, 2011.

----, Rakyat Kecil, Islam dan Politik, Yogyakarta: Gading, 2013.

---- (ed.), Contemporary Developments in Indonesian Islam: Explaining the “Conservative Turn”, Singapore: ISEAS, 2013.

Bruinessen, Martin van and Julia Day Howell, Sufism and the "Modern" in Islam, London: I.B.Tauris, 2007.

Bruinessen, Martin van and Farid Wajidi, 'Syu'un Ijtima'iyah and the Kiai Rakyat: Traditionalist Islam, Civil Society and Social Concerns", in Indonesian Transitions: Work in Progress, ed. by Henk Schulte Nordholt and Ireen Hoogenboom, Yogyakarta: Pustaka Pelajar, 2006,

Chomsky, Noam, American Power and the New Mandarins: Historical and Political Essays, New York: Pantheon, 1969.

Couperus, Louis, De Stille Kracbt, Amsterdam: Kessinger Publishing, 1900.

Daud, Alfani, Islam dan Masyarakat Banjar: Deskripsi dan Analisa Kebudayaan Banjar, Jakarta: Raja Grafindo Persada, 1997.

Dijk, C. van, Rebellion Under the Banner of Islam: The Darul Islam in Indonesia, The Hague: Martinus Nijhoff, 1981.

---- (ed.), Islam en Politiek in Indonesië, Muiderberg: Coutinho, 1988.

Djajadiningrat, Hoesein, "Critische Beschouwing van de Sadjarah Banten”, PhD Thesis, Leiden: Leiden University, 1913.

Doorenbos, Johan, "De Geschriften van Hamzah Pansoeri”, PhD Thesis, Leiden: Leiden University, 1933. 
In the Tradition or Outside? Reflections on Teachers and Influences

Doorn, J.A.A. van and W.J. Hendrix, Ontsporing Van Geweld: Over Het Nederlands/Indisch/Indonesisch Conflict, Rotterdam: Universitaire Pers, 1970.

Drewes, Gerardus Willebrordus Joannes, "Drie Javaansche Goeroe's: hun leven, onderricht en messiasprediking", PhD Thesis, Leiden: Leiden University, 1925.

----, "D.A. Rinkes; A note on his life and work (Met portret)", Bijdragen tot de Taal-, Land-en Volkenkunde (BKI), vol. 117, no. 4, 1961, pp. 417-35.

Edel, Jan, "Hikajat Hasanoeddin”, PhD Thesis, Meppel: Utrecht University, 1938.

Emeritus, Cees Fasseur, De Indologen: Ambtenaren voor de Oost 1825-1950, Amsterdam: B. Bakker, 1993.

Farid Wajidi, "Syarikat dan Eksperimentasi Rekonsiliasi Kulturalnya (Sebuah Pengamatan Awal)", Tashwirul Afkar, vol. 15, 2003, pp. 55-79.

Feener, R. Michael, Sharia and Social Engineering: The Implementation of Islamic Law in Contemporary Aceh, Indonesia, Oxford: Oxford University Press, 2013.

"Feminisme dan Al-Qur'an: Wawancara dengan Riffat Hassan", Ulumul Qur'an, vol. 3, no. 5, 1994.

Fenema, Joyce van, Een Kwestie van Kię̧en, The Hague: BZZTôH, 1995.

Geertz, Clifford, Agricultural Evolution: The Process of Ecological Change in Indonesia, Berkeley: University of California Press, 1963.

Gough, Kathleen, "New Proposals for Anthropologists", Current Anthropology, vol. 9, no. 5, 1968, pp. 403-7.

Gurr, Ted Robert, Why Men Rebel, New York: Princeton University Press, 1970.

Haasse, Hella Serafia, Oeroeg, The Black Lake, 1948.

Hassan, Riffat, "Teologi Perempuan dalam Tradisi Islam”, Ulumul Qur'an, vol. 1, no. 4, 1990 .

Hurgronje, Christiaan Snouck, Mekeka, Bd.II: Aus Dem Heutigen Leben, Den Haag: Nijhoff, 1889.

----, Mekeka in the Latter Part of the 19th Century, Leiden: Brill, 1931.

Ibrahim, Saad Eddin, "Anatomy of Egypt's Militant Islamic Groups: Methodological Note and Preliminary Findings", International Journal 
of Middle East Studies, vol. 12, no. 04, 1980, pp. 423-53 [http:/ /dx.doi. org/10.1017/S0020743800031238].

Jedamski, Doris, "Balai Pustaka: A Colonial Wolf in Sheep's Clothing”, Archipel, vol. 44, no. 1, 1992, pp. 23-46 [http://dx.doi.org/10.3406/ arch.1992.2848].

Johns, Anthony H., "An Islamic System or Islamic Values? Nucleus of a Debate in Contemporary Indonesia", in Islam and the Political Economy of Meaning: Comparative Studies of Muslim Discourse, ed. by William R. Roff, London: Croom Helm, 1987.

Jong, J.P.B. de Josselin de, De Maleische Archipel als Ethnologisch Studieveld, Leiden: Ginsberg, 1935.

Kaptein, Nico J.G., Islam, Colonialism and the Modern Age in the Netherlands East Indies: A Biography of Sayyid Uthman (1822 - 1914), Leiden: Brill Academic Publishers, 2014.

Koningsveld, P. Sj. van, Snouck Hurgronje's "Izhaar oel-Islaam”: Een Veronachtraamd Aspect van de Koloniale Geschiedenis, Leiden: Faculteit der Godgeleerdheid, 1893.

Kraemer, H., "Een Javaansche Primbon Uit de Zestiende Eeuw", PhD Thesis, Leiden: Leiden University, 1921.

Laffan, Michael F., The Makings of Indonesian Islam: Orientalism and the Narration of a Sufi Past, New York: Princeton University Press, 2011.

Latief, Hilman, Islamic Charities And Social Activism Welfare, Dakwah And Politics In Indonesia, 2012.

Lombard, Denys, "Islam et Sinité", Archipel, vol. 30, no. 1, 1985, pp. 73-94 [http://dx.doi.org/10.3406/arch.1985.2245].

----, Le Carrefour Javanais: Essai d'histoire Globale, vol. 3, de l'EHESS edition, Paris: Ecole Hautes Etude en Sciences Sociales, 1990.

Lombard, Denys and Ecole francaise d'Extreme-Orient, Le Sultanat d'Atjeh au Temps d'Iskandar Muda (1607-1636), Paris: Ecole Francaise d'Extreme-Orient, 1967.

Marcoes-Natsir, Lies M. and Johan H. Meuleman (eds.), Wanita Islam Indonesia dalam Kajian Tekstual dan Kontekstual: Kumpulan Makalah Seminar, Jakarta: INIS, 1993.

Masudi, Masdar Farid, Agama Keadilan: Risalah Zakat (Pajak) dalam Islam, Jakarta: Pustaka Firdaus, 1991.

Mujiburrahman, "Feeling Threatened: Muslim-Christian Relations in 
In the Tradition or Outside? Reflections on Teachers and Influences Indonesia's New Order", PhD Thesis, Utrecht : Utrecht University, 2006.

Multatuli, Max Havelaar of de Koffiveilingen der Nederlandsche Handelmaatschappy, ed. by A. Kets-Vree, Amsterdam: Prometheus, 1960.

Nieuwenhuijze, Christoffel Anthonie Olivier van, "Samsu 'l-Dīn van Pasai: bijdrage tot de kennis der Sumatraansche mystiek", PhD Thesis, Leiden: Leiden University, 1945.

Noorhaidi, "Laskar Jihad: Islam, Militancy and the Quest for Identity in Post-New Order Indonesia”, PhD Thesis, Utrecht: Utrecht University, 2005.

Otterspeer, W. and L.H. Enklaar (eds.), "Leiden Orientalists and the Christian Mission”, in Leiden Oriental Connections: 1850 - 1940, Leiden: E.J. Brill, 1989.

Parlindungan, Mangaradja Onggang, Pongkinangolngolan Sinambela gelar Tuanku Rao: terror agama Islam Mąhab Hambali di tanah Batak 1861 1833, Djakarta: Tandjung Pengharapan, 1964.

Perron, E. Du, Het Land van Herkomst, ed. by Francis Bulhof and G.J. Dorleijn, Amsterdam: Van Oorschot, 1935.

Pijper, G..., "Het Boek der Duizend Vragen”, PhD Thesis, Haarlem: Leiden University, 1924.

----, “De Vrouw en de Moskee”, in Fragmenta Islamica, Leiden: Brill, 1934.

----, "De Strijd om de Monogamie", Koloniale Studiën, vol. 21, 1937, pp. 476-190.

----, Studiën Over de Geschiedenis van de Islam in Indonesia 1900-1950, Leiden: Brill, 1977.

----, "Het Reformisme in de Indonesische Islam", in Studiën Over de Geschiedenis van de Islam in Indonesia 1900-1950, Leiden: Brill, 1977.

----, Fragmenta Islamica: Beberapa Studi Mengenai Sejarah Islam di Indonesia Abad $X X$, trans. by Tudjimah, Jakarta: Penerbit Universitas Indonesia, 1987.

Ricklefs, M.C. (ed.), Hermanus Johannes de Graaf, and Theodore G. Th Pigeaud (trans.), Chinese Muslims in Java in the 15th and 16 th Centuries: The Malay Annals of Semarang and Cerbon, Clayton: Monash University, 1984.

----, "Six Centuries of Islamization in Java", in Conversion to Islam, ed. by Nehemia Levtzion, New York: Holmes \& Meier Pub, 1978. 
Martin van Bruinessen

----, The Seen and Unseen Worlds in Java, 1726-1749: History, Literature, and Islam in the Court of Pakubuwana II, Honolulu: University of Hawaii Press, 1998.

----, Polarising Javanese Society: Islamic and Other Visions (c. 1830-1930), Singapore: NUS Press, 2007.

Rinkes, Douwe Adolf, "Abdoerraoef van Singkel: Bijdrage tot de kennis van de mystiek op Sumatra en Java", PhD Thesis, Leiden, 1909.

----, Nine Saints of Java, ed. by Alijah Gordon, trans. by H.M. Froger, Kuala Lumpur: Malaysian Sociological Research Institute, 1996.

Roolvink, R. et al., Historical Atlas of the Muslim Peoples, Djambatan, 1957. ----, Bahasa Jawi, de Taal van Sumatra, Leiden: Universitaire Pers, 1975.

Schrieke, Bertram Johannes Otto, "Bijdrage tot de Bibliografie van de Huidige Godsdienstige Beweging ter Sumatra's Westkust”, Tijdschrift voor Indische Taal-, Land-en Volkenkunde, vol. 59, 1920, pp. 249-325.

----, "Allerlei over de besnijdenis in den Indischen Archipel", Tijdschrift voor Indische Taal-, Land-en Volkenkunde, vol. 60, 1921, pp. 373-578.

----, "Allerlei over de besnijdenis in den Indischen Archipel", Tijdschrift voor Indische Taal-, Land-en Volkenkunde, vol. 61, 1922, pp. 1-94.

Schrieke, B.J.O., "Het boek van Bonang", PhD Thesis, Haarlem: Leiden University, 1916.

Schrieke, Johannes Otto Schrieke, "De Strijd Onder de Arabieren in Pers en Literatuur", Notulen van het ... Bataviaasch Genootschap, vol. 58, 1921, pp. 189-240.

Scott, James C., Domination and the Arts of Resistance: Hidden Transcripts, New Haven: Yale University Press, 1990.

Siegel, James T., The Rope of God, Berkeley: University of California Press, 1969.

----, Solo in the New Order: Language and Hierarchy in an Indonesian City, Princeton: Princeton University Press, 1993.

----, The Rope of God, Ann Arbor: University of Michigan Press, 2000.

Snouck Hurgronje, Christiaan, De Atjèhers, vol. 2, Batavia: Landsdrukkerij, 1893.

Steenbrink, Karel A., "Pesantren, Madrasah, Sekolah: Recente Ontwikkelingen in Indonesisch Islamonderricht”, PhD Thesis, Nijmegen: Katholieke Universiteit te Nijmegen, 1974. 
In the Tradition or Outside? Reflections on Teachers and Influences

Steenbrink, Karel A., Beberapa Aspek tentang Islam di Indonesia Abad ke-19, Jakarta: Bulan Bintang, 1984.

----, Pesantren, Madrasah, Sekolah: Pendidikan Islam dalam Kurun Modern, Jakarta: LP3ES, 1986.

Suminto, H. Aqib, Politik Islam Hindia Belanda, Jakarta: LP3ES, 1985.

Syuan Yuan Chiou, "In Search of New Social and Spiritual Space: Heritage, Conversion, and Identity of Chinese-Indonesian Muslims", $\mathrm{PhD}$ Thesis, Utrecht: Utrecht University, 2012.

Teljeur, D., Harry A. Poeze, and J.W. Schoorl (eds.), Excursies in Celebes, Leiden: KITLV, 1991.

Thrupp, Sylvia L., Millennial Dreams in Action: Essays in Comparative Study, The Hague: Mouton, 1962.

Wahib, Ahmad, Pergolakan Pemikiran Islam: Catatan Harian Ahmad Wabib, ed. by Djohan Effendi and Ismed Natsir, Jakarta: LP3ES, 1981.

Wahid, Din, "Nurturing the Salafi Manhaj: A Study of Salafi Pesantrens in Contemporary Indonesia”, PhD Thesis, Utrecht: Utrecht University, 2014.

Wertheim, Willem Frederik, Indonesian Society in Transition: A Study of Social Change, The Hague and Bandung: Van Hoeve Ltd, 1969.

----, Counter-Insurgency Research at the Turn of the Century: Snouck Hurgronje and the Aceh War, Sociologische Gids 19/5-6, 1972.

----, Elite en Massa: Een Bijdrage tot Ontmaskering van de Elitewaan, Amsterdam: Kritiese Bibliotheek / Van Gennep, 1975.

----, Indonesië van Vorstenrijk tot Neo-Kolonie, Meppel: Boom, 1978.

Zoetmulder, Petrus J., "Pantheïsme en Monisme in de Javaansche SoeloekLiteratuur", PhD Thesis, Leiden: Leiden University, 1935.

Zoetmulder, P.J., Pantheism and Monism in Javanese Suluk Literature, Leiden: KITLV Press, 1994. 